\title{
أثر التوجه الريادي في تمقيق النجاح الاستراتيجي في سلطة هنطقة العقبة الاقتصادية
}

\author{
الدكتور \\ عطاןلاله أحمد الحسبان \\ أستاذ مشارك محاسبة \\ جامعة العقبة للتكنولوجيا - الأردن
}

\author{
الدكتور \\ هسام مبارك الذنيبات \\ أستاذ مساعد إدارة الأعمال \\ جامعة العقبة للتكنولوجيا - الأردن
}

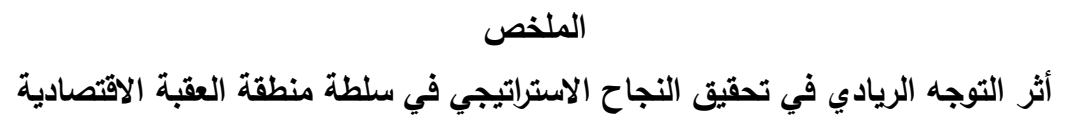

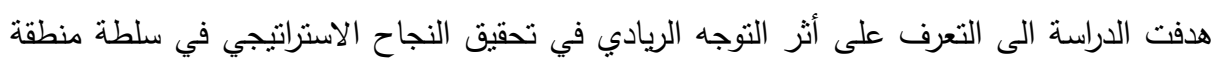

العقبة الاقتصادية. ولتحقيق أهداف هذه الدراسة، تم إختيار المفوضين والمديرين ومساعدي المديرين التيرين ورؤساء الاقسام ورؤساء الثعب في سلطة منطقة العقبة الاقتصادية والبالغ مجموعهم (ع آ؟م) ونظراً

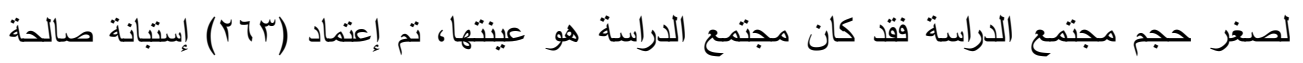
للمعالجة والتحليل بإستخدام برنامج (SPSS.20) الإحصائي في التحليل الاحصائي للبيانات بالاعتماد على عدة مقاييس من أهمها المتوسطات الحسابية والاتحرافات المعيارية وتحليل الإنحدار المتعدد وتحليل الإنيل

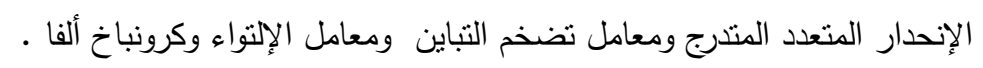

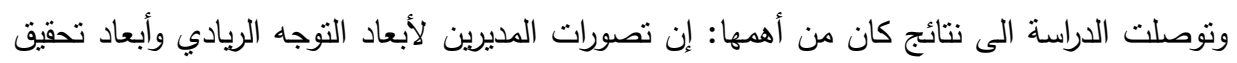

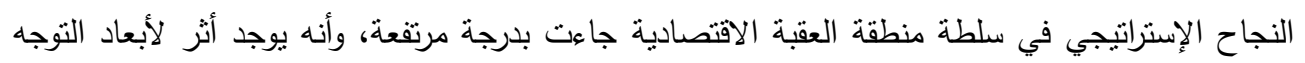

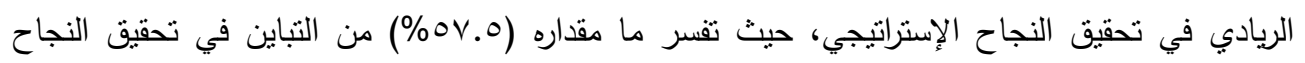

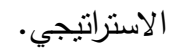

وتوصي الدراسة بضرورة تنبي مفهوم التوجهات الريادية والعمل على الاستثمار بها، وتوفير الوسائل والأساليب التي تساعد على نكوين هذه التوجهات في السلطة، كذلك العمل على تبني السياسات والإجراءات التي من شانها أن تعمل عل تحقيق النجاح الاستراتيجي. 


\section{Abstract \\ The Impact of the Entrepreneurial Orientation in Achieving Strategic Success in Aqaba special economic zone \\ The study aimed at identifying the impact of entrepreneurial}

orientation in achieving strategic success in Aqaba special economic zone. To achieve the objectives of this study, the commissioners of the higher and middle administrations in Aqaba Aqaba Economic Zone (334) were selected. Due to the small size of the study population, a total of (263) data were valid to be processed and analyzed afterwards with the statistical program(SPSSv.20) in the statistical analysis of these data based on many measures the most important of them are: arithmetic means, standard deviations, multiple regression analysis, step wise regression analysis, variance inflation coefficient, cronbach's alpha coefficient. The study found a set of results, the most important of which were: The perception of managers toward entrepreneurial orientation, and achieving strategic success in the Aqaba special economic zone, came at a high level. The existence of the Entrepreneurial Orientation effect on the achieving strategic success, which explains the amount of effect to $(57.5 \%)$ of the variation in achieving strategic success.

The study recommends the adoption of the concept of entrepreneurial orientation and investment, providing the means and methods that help to shape these trends in power, as well as work to adopt policies and procedures that would work to achieve strategic success.

Key Words: Entrepreneurial Orientation, Achieving Strategic Success, Aqaba special economic zone 
أدت التطورات العديدة والمتسارعة السريعة في عالم اليوم إلى ظهور توجهات إدارية جديدة،

تمثل فلسفة مغايرة لما كانت عليه أفكار الإدارة في الماضي، وانعكست هذه الفلسفة على المؤسسات

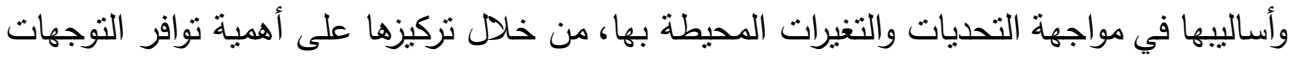
الريادية والتي تُعد الأساس في بناء المنظمات وتطويرها.

أن نهج التوجه الريادي اكتسب أهميه بالغة في منظمات الأعمال اليوم، وتعد أحد أهم السياسات التي تساعد على رفع كفاءة أداء المؤسسات، كما ينظر إليها على أنها تمثل اسنتماراً مستقبلياً ذا عائد ومردود للمنظمة (Hafeez, et.al 2011). والتوجه الريادي هو الأساس لنجاح الريادة المؤسسية، فالتوجه الريادي هو مفهوم أساسِ في أدبيات الإدارة الإستراتيجية ، وهدفه تحقيق

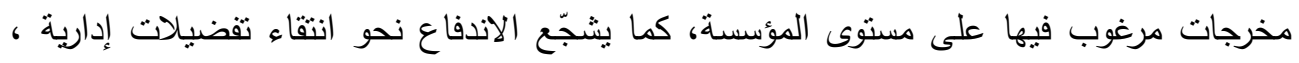

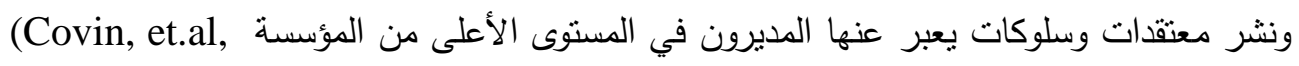

ويثير كل من (Herath, \& Mahmood, 2013) إلى أن مصطلح الريادة جاء كاستجابة للتغيرات التنظيمية وبخاصة في مجال الأعمال حيث تعني (Entrepreneurship) بأنها قدرات مكتسبة نسمح بالسلوك والعمل في سياق معين، ويتكون محتواها من من معارف ومهارات

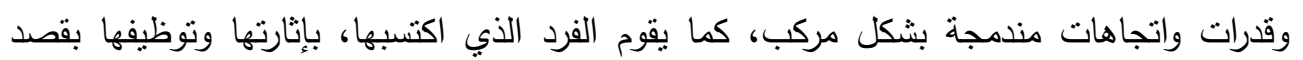
مواجهة مشكلة ما وحلها في وضعية محددة. ويركز كل من (Huang, et.al, 2013) إن التوجهات

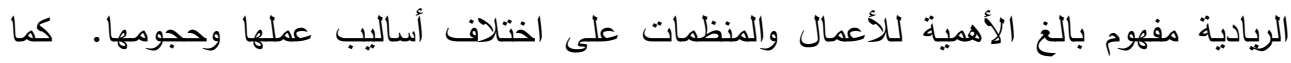

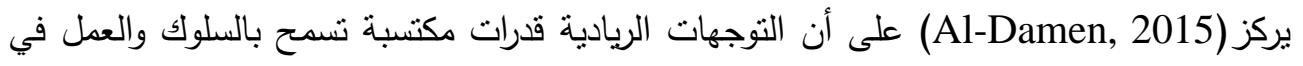

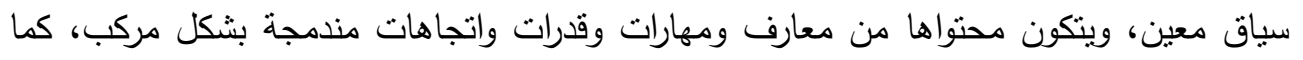
يقوم الفرد الذي اكتسبها، بإثارتها وتوظيفها بقصد مواجهة مشكلة ما وحلها في وضعية محددة. وقدان

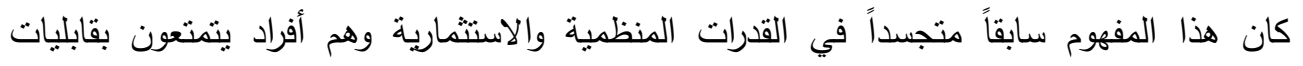
وقدرات تحمل المخاطر وقبول المجازفة المحسوبة وزيادة الفرص والتخطيط العلمي السليم والإدارة

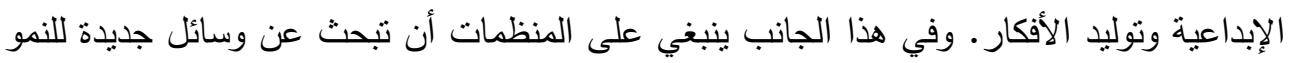

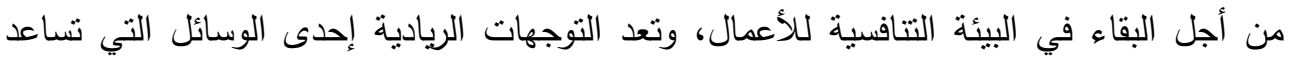
المنظمات في تعزيز موقعها التتافسي (Dahleez, \& Migdad, 2013). كما بين (Dess, et.al.,2007) بأن الريادة تمثل ما تمنلكه المنظمة من معارف وقدرات

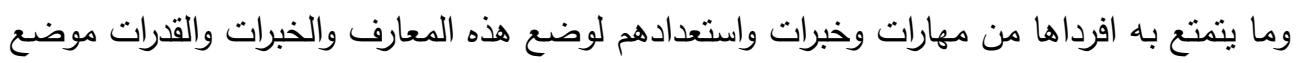

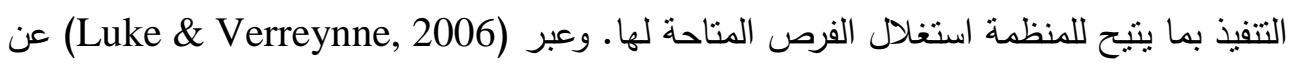


الريادة بانها تمنل "عملية اتخاذ أنشطة ريادية من خلال التركيز بشكل متزامن على إيجاد الفرص،

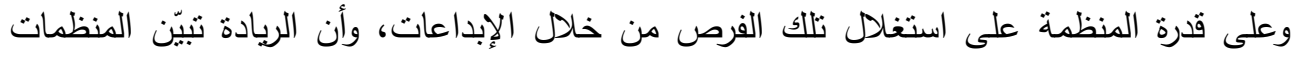
التي تتكامل أنشطتها لتحقيق الإبداع الناجح كوسيلة رئيسة لاستغلال تلأك الفرص في البيئة التتافسية

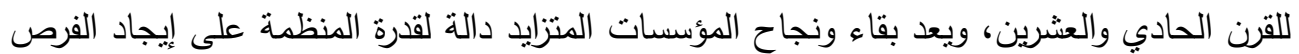

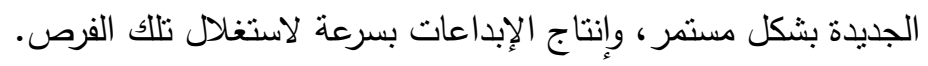

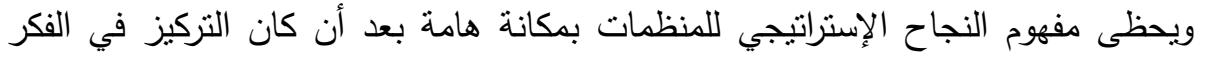

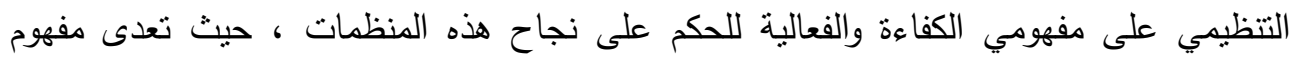
النجاح الاستراتيجي هذين المفهومين إلى مدى استثمار المنظمات للقدرات العقلية في نقل المعرفة

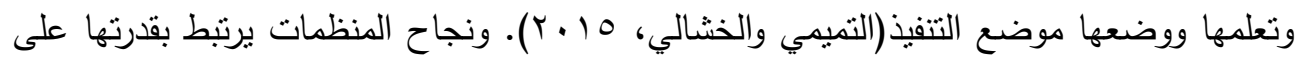

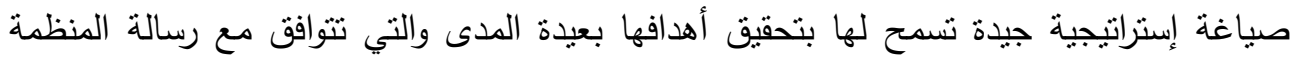
ورؤيتها ، بالإضافة إلى تتفيذ جيد وفعال لتلك الاستراتيجية ويمكن القول أن البقاء ضمن بيئة المنافسة والاستمرار بالعمل هو جوهر النجاح الإستراتيجي، والمرتكز الأساس الذي يمكن أن تتطلق

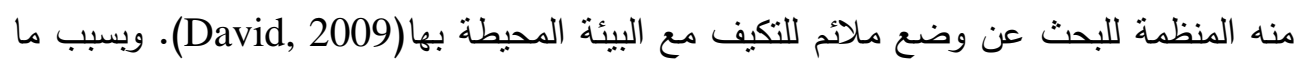
تواجهه منظمات الأعمال في الوقت الحاضر من تحديات كبيرة تتمثل في شدة المنافسة وسرعة لهنة التغير في البيئة التي تعمل بها ، تسعى كافة هذه المنظمات إلى الوصول للى للنجاح الاستراتيجي

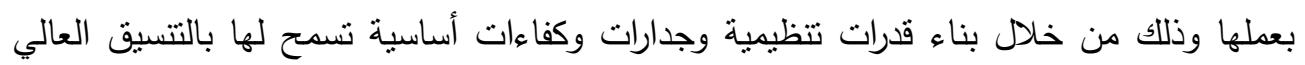
لاستخدام الموارد المتاحة بكفاءة وفعالية نسهم في الوصول إلى نتائج أداء متميزة ومتقوقة عن فئن

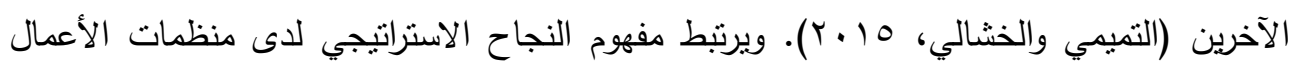
بالتكيف البيئي والنمو، أي تحقيق البقاء، حيث أن الاستمرار والتفاعل في ظل البيئة المتغيرة ينطلب

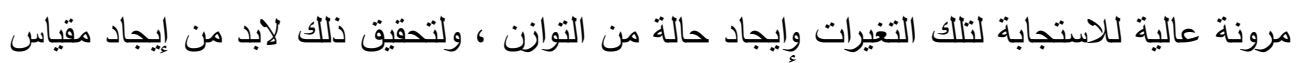
لتقييم أداء المنظمة بحيث يتلاءم هذا الأداء مع كل مرحلة من مراحل حياتها (الحلالمة والعزاوي،

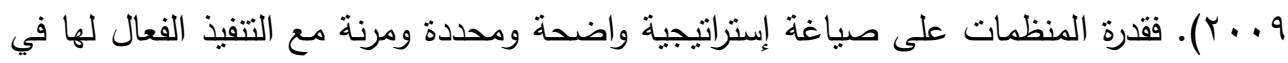

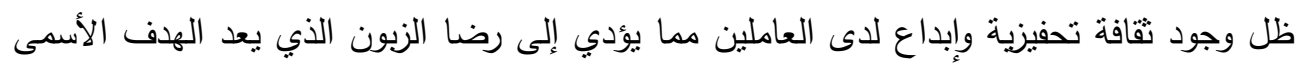

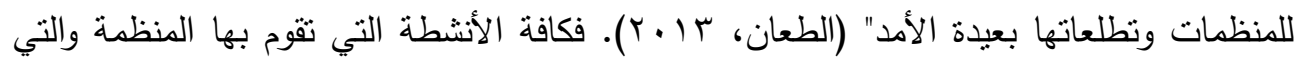

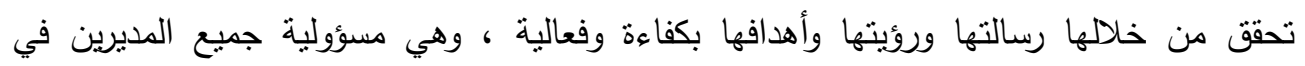
المنظمة وبمختلف مستوياتهم الإدارية(Meibodi and Monavvarian, 2010). وسلطة منطقة العقبة الاقتصادية كغيرها من المنظمات تواجه تحديات كبيرة، وخاصة في

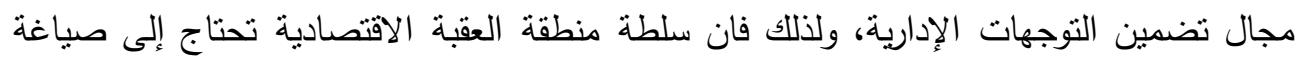

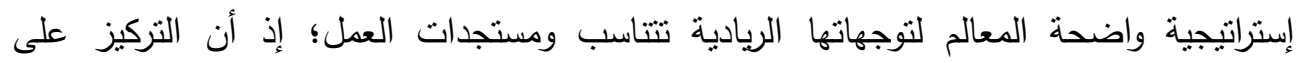


النوجهات الريادية في الهنظمة ينطلب إجراء تغييرات جوهرية في كل السياسات الإدارية التي تؤثر في تنخيص التوجهات اللازمة بهدف توفيرها وتطويرها لتحقيق النجاح الإنتراتيجي. مشكلة الدراسة:

تواجه منطقة العقبة الاقتصادية تغيرات جوهرية وتوجهات جديدة وتطورات حديثة نلمسها في مختلف المجالات، فمنذ اطلاق سلطة منطقة العقبة الاقتصادية الخاصة في محافظة العقبة عام

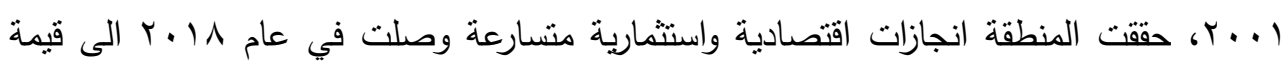

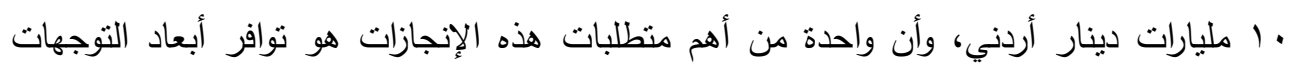

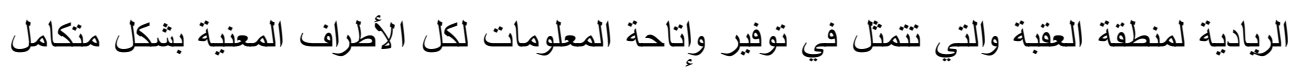

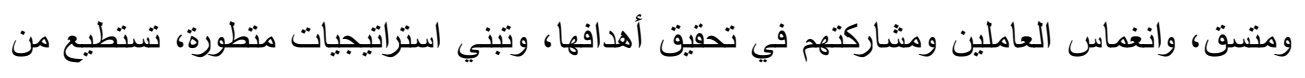
خلالها الحصول على المزايا الإيجابية والفعَالة والتي تتعكس على منطقة العقبة الاقتصادية وتميزها

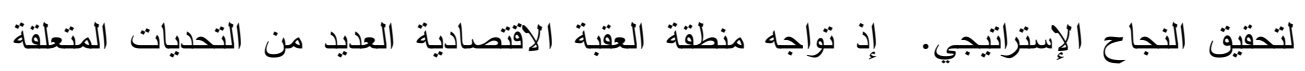

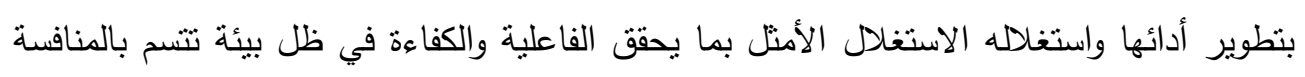

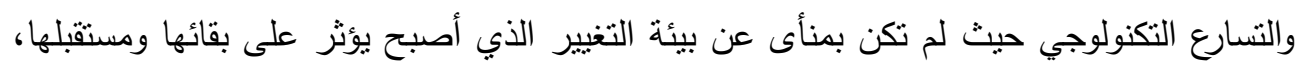

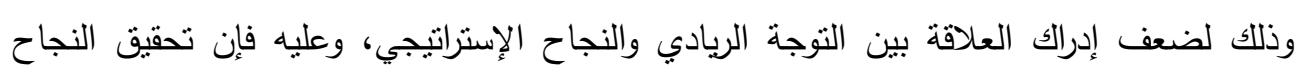

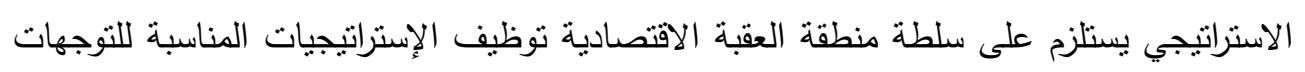

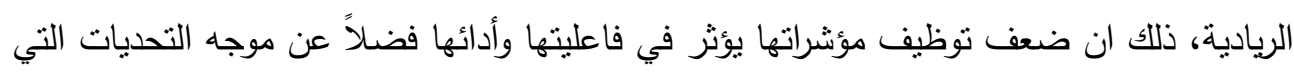

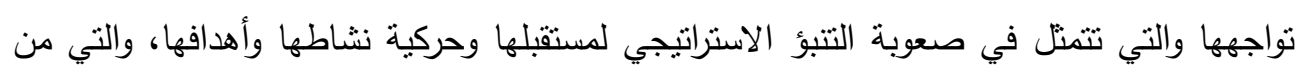

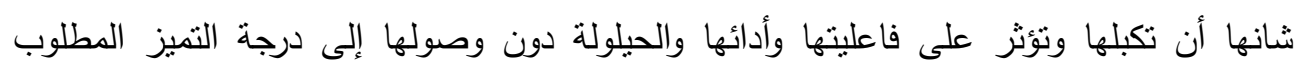

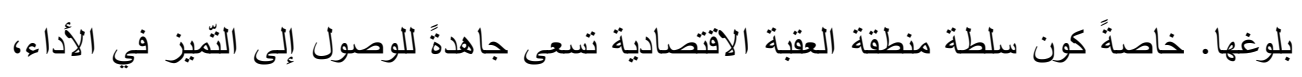

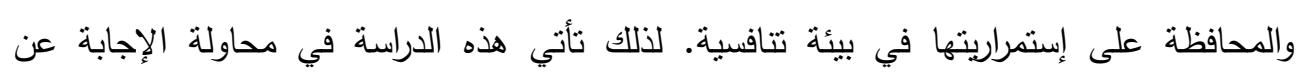

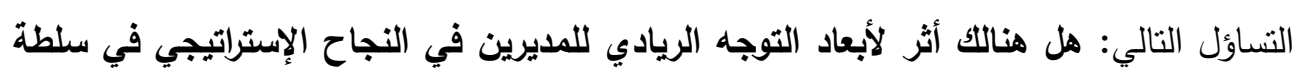

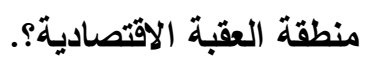




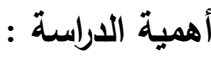

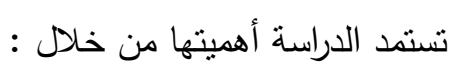

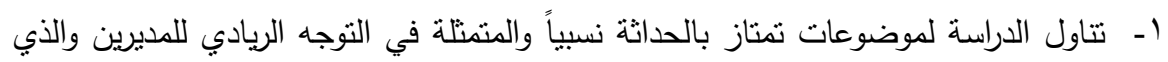

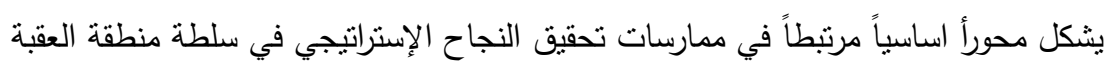
الاقتصادية.

r- أهمية القطاع الذي سيتم تطبيق الدراسة عليه وهي سلطة منطقة العقبة الاقتصادية، والتي كئي

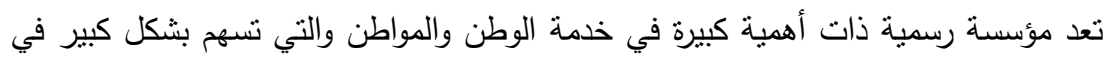
رفد الموازنة العامه للاولة.

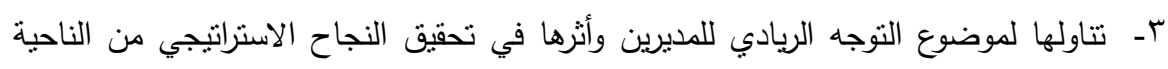

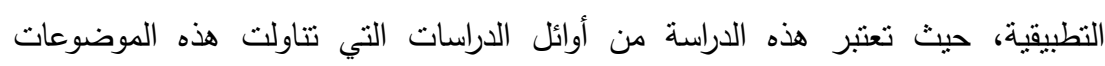
وتطبيقها خصوصاً في سلطة منطقة العقبة الاقتصادية.

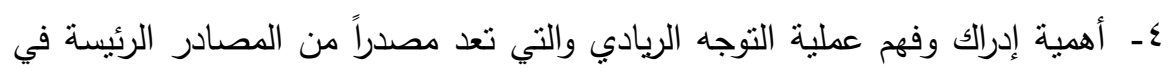

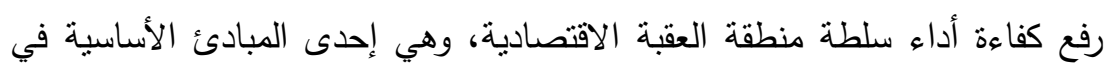
مجال صنع ريادية الأعمال. 0- تخدم هذه الدراسة منطقة العقبة الاقتصادية بما يمكن أن تقدمه من معلومات عن الإدية

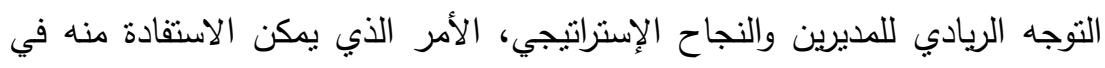

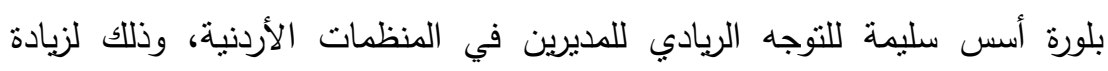

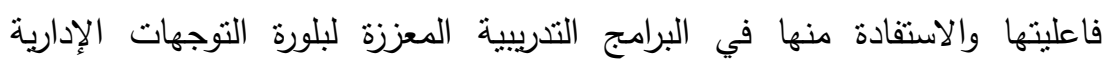

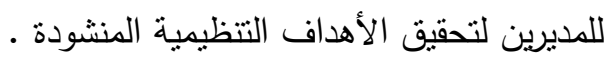

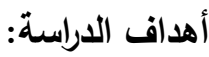

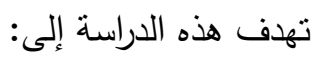

1- التعرف على أثر أبعاد النوجه الريادي للمديرين في النجاح الاستراتيجي في منطقة

$$
\text { العقبة الاقتصادية. }
$$

ץ- التعرف على مدى توافر أبعاد التوجه الريادي للمديرين بأبعاده (البعد الإبداعي، والبعد ألاستباقي، وبعد المخاطرة، والبعد الاستقالالي، والبعد التنافسي).

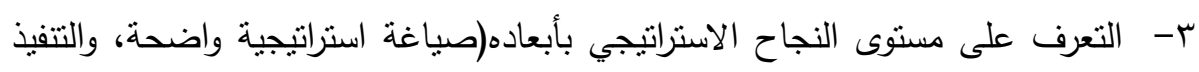

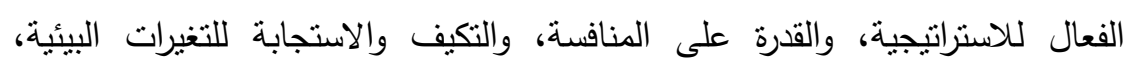
والاستمرار بالنمو) من وجهة نظر الديرين في سلطة منطقة العقبة الاقتصادية. 
ع- تقديم توصيات ومقترحات لمتخذي القرار في سلطة منطقة العقبة الاقتصادية مبنية

على نتائج الدراسة، تهدف إلى توضيح أهمية الاهنمام بعملية التوجه الريادي للمديرين والنجاح الإستراتيجي للمحافظة على مكانتها المتميزة.

$$
\text { فرضيات الاراسة : }
$$

تمحورت هذه الدراسة حول الفرضيات الآتية:

- الفرضية الرئيسة :لا يوجد أثز ذو دلالة إحصائية عند مستوى دلالة

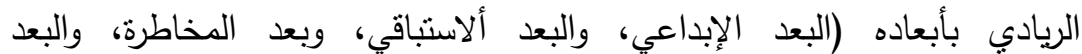

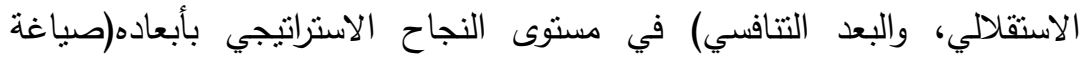
استراتيجية واضحة، والتتفيذ الفعال للاستراتيجية، والقدرة على المنافسة، والتكيف والاستجابة للتغيرات البيئية، والاستمرار بالنمو ) في سلطة منطقة العقبة الاقتصادية. وينبثق من هذه الفرضية الفرضيات الفرعية التالية: - الفرضية الفرعية الأولى :لا يوجد أثر ذو دلالة إحصائية عند مستوى دلالة (0.05 م) للتوجه

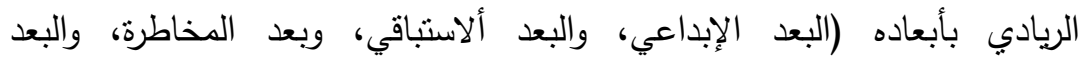
الاستقلالي، والبعد التتافسي) في صياغة استراتيجية واضحة في سلطة منطقة الإنة العقبة الاقتصادية.

-الفرضية الفرعية الثانية : لا يوجد أثز ذو دلالة إحصائية عند مستوى دلالة (0.05 $\alpha$ اللتوجه

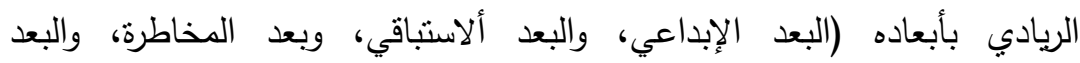

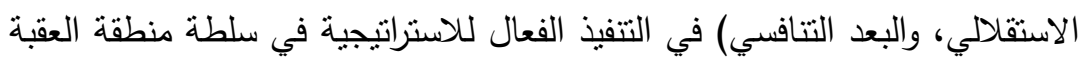

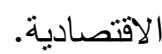

-الفرضية الفرعية الثالثة :لا يوجد أثز ذو دلالة إحصائية عند مستوى دلالة (20.05 ) للتوجه

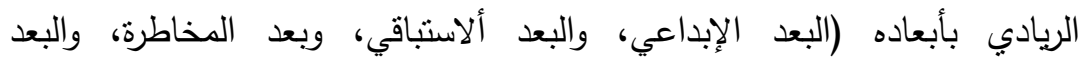
الاستقلالي، والبعد التتافسي) في القدرة على المنافسة في سلطة منطقة العقبة العبدة

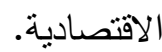

-الفرضية الفرعية الرابعة :لا يوجد أثز ذو دلالة إحصائية عند مستوى دلالة (1) 0.05$)$ للتوجه

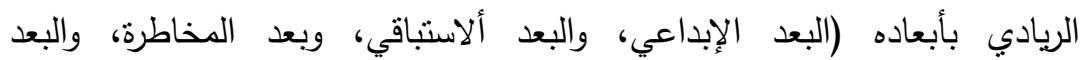

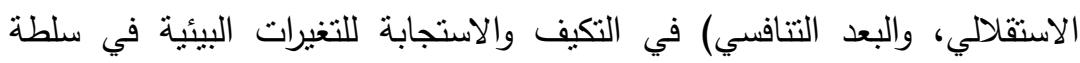
منطقة العقبة الاقتصادية.

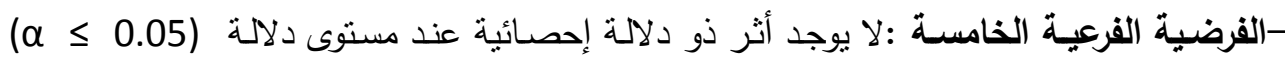

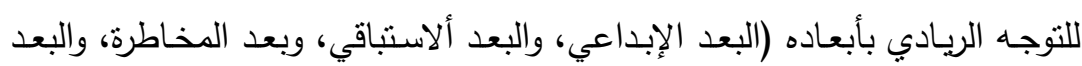


الاسـتقلالي، والبعـد التنافسي) فـي الاسـتمرار بـالنمو فـي سـلطة منطقـة العقبـة

الاقتصادية.

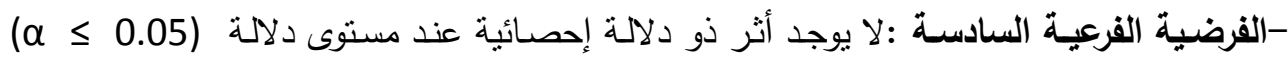

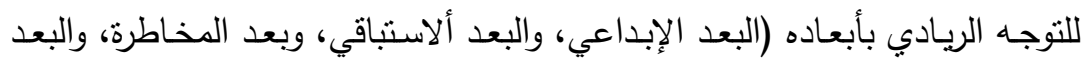

الاسـتقلالي، والبعـد التتافسي) فـي رضــا المـراجعين في ســلطة منطقـة العقبـة

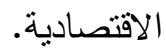

التعريفات الاجرائية

أولاً: المتغير المستقل: التوجه الريادي: هو توجه استراتيجي يتبناه المديرون ،ويؤثر في أداء سلطة

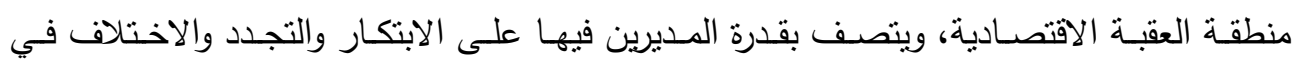

$$
\text { المنتجات والخدمات المقدمة. }
$$

\section{ويتكون من الأبعاد الفرعية الآتية :}

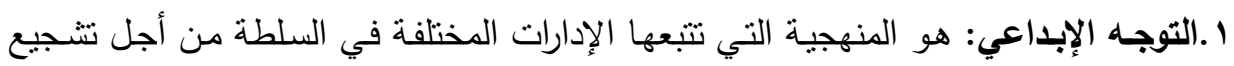
العاملين فيها على تجربة وسائل جديدة مبتكرة وتقديم الأفكار والخدمات الجديدة بطريقة

$$
\text { منظمة ومدعمة تسهم في تحقيق أهداف العمل. }
$$

r.التوجه نحو المخاطرة: هو السلوك الفعّال للإدارات المختلفة في السلطة في الرغبة بتفويض

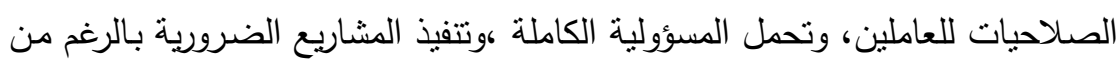

عدم تأكدهم من نتائجها من أجل تحقيق الأهداف في حالة المخاطرة أو عدم التأكد. ץ.التوجه الاستباقي هو التوجه العام للإدارات المختلفة في السلطة نحو التغيير الاهن في أساليب

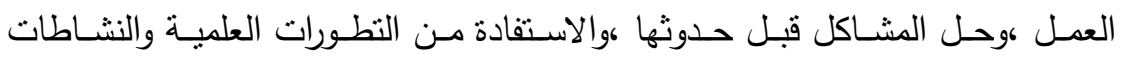
الجديدة؛ لتحقيق أهداف العمل، والإعداد المدروس للمستقبل. ؛ .التوجه التنافسي: هو التوجه الذي تتجع خلاله الإدارات المختلفة في السلطة العاملين على التى

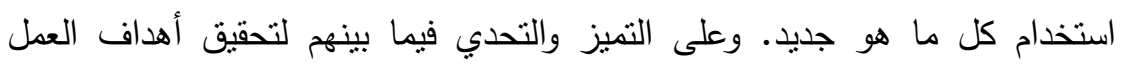

$$
\text { بمستوى عال من الأداء الفردي والجماعي. }
$$

ه. التوجه الاستقلالي: هو التوجه الذي تسعى خلاله الإدارات المختلفة في السلطة إلى تمكين

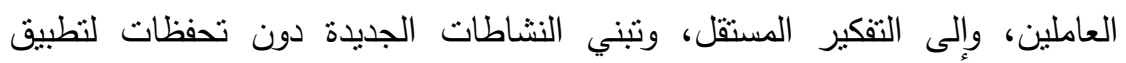

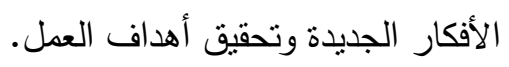

ثانياً- المتغير التابع: النجاح الاستراتيجي: هو تنبني سلطة منطقة العقبة الاقتصادية

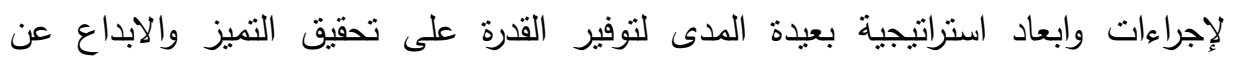


المنافسين والمتمتل في القطاع الخاص من خلال مفاهيم اوسع واكثر شمولية من الكفاءة والفعالية والنجاح التنظيمي.

$$
\text { وتتمثل ابعاد المتغير التابع في هذه الدراسة بما يلي: واني }
$$

1- صياغة استراتيجية واضحة: وتعني أن تضع سلطة منطقة العقبة الاقتصادية استراتيجية واضحة المعالم تتميز بقابليتها للتنفيذ والنطبيق، ولها نتائج إيجابية محددة وواضحة، قادره على تحديد اساليب العمل بشكل مناسب وتعكس توجهات الهيئات المستقلة، وهي مسؤولية جميع المديرين بمختلف مستوياتهم الإدارية في تلك الهيئات. r- التنفيذ الفعال للاستراتيجية: وهو ان نسعى السلطة الى ايجاد وجهات نظر داعمة

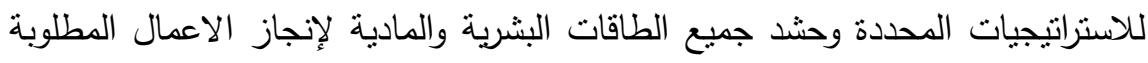
ضمن الجداول الزمنية المحددة لها وبدون اخطاء قد تؤدي الى فنشل هذه الاستراتيجية.

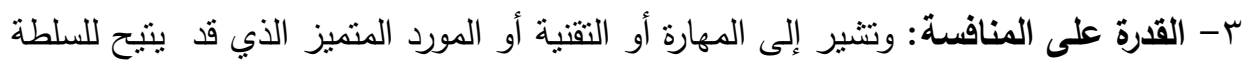
إنتاج قيم ومنافع وخدمات للمواطنين-منلقي الخدمة من السلطة -بشكل يزيد عما يقدمه الفها

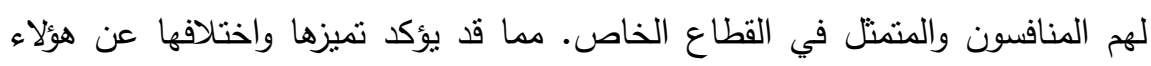

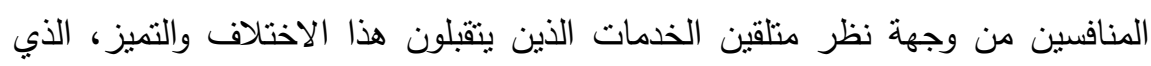
يحقق لهم المزيد من المنافع والخدمات والقيم التي تثقوق على ما يقدمه لهم المنافسون الآخرون. ع - التكيف والاستجابة للتغيرات البيئية: ويعني قدرة سلطة منطقة العقبة الاقتصادية على التتبؤ بالظروف والمشكلات سواء الداخلية او الخارجية التي من الممكن مواجهتها وإيجاد السبل

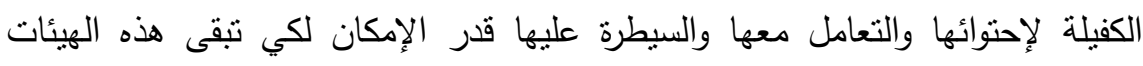
منتجة ومنافسة.

ه- الاستمرار بالنمو: ويشير إلى التحسين والنطوير المستمر والمهم والسريع في السلطة

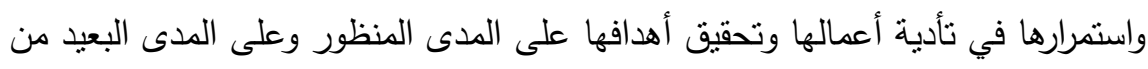

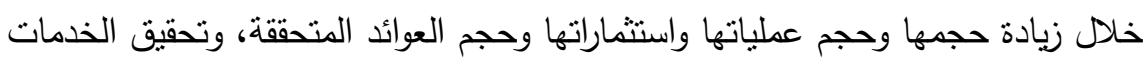
والمنطلبات المتزايدة والمتتوعة للمواطنين. 
أنموذج الدراسة
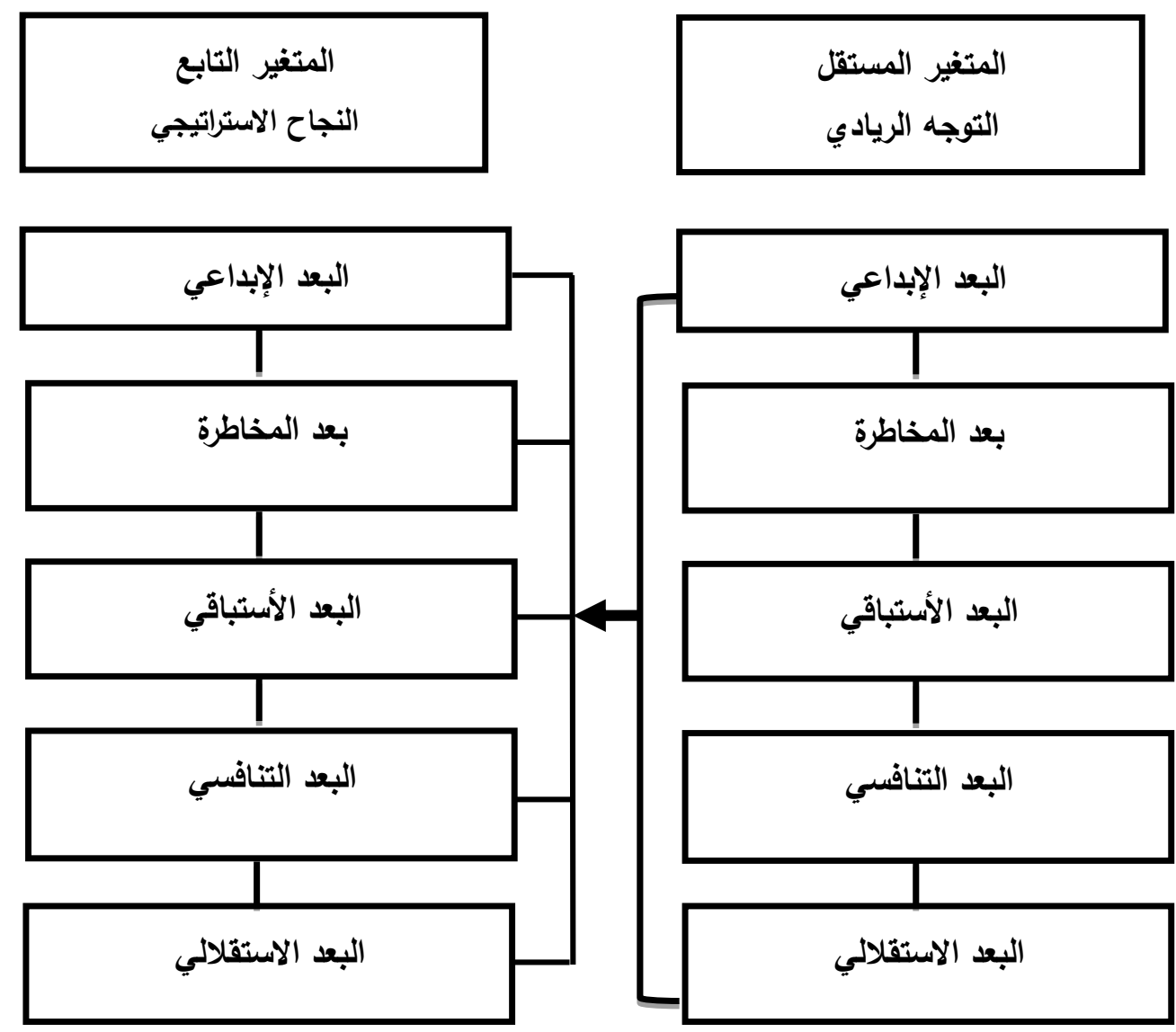

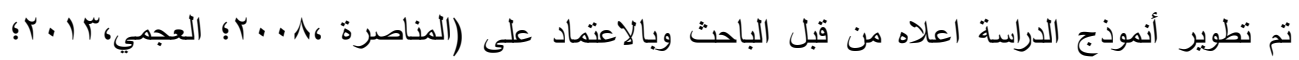

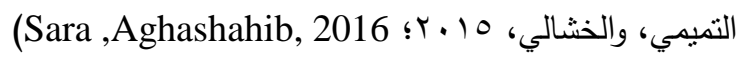
منهجية الاراسة :

استتدت الدراسة على المنهج الوصفي - التحليلي في تغطية متطلبات الإطار النظري وعرض النار الدراسات السابقة فضلاً عن إجراء المسح المكتبي إزاء الطروحات النظرية المتعلقة بمتغيرات وأبعاد الودية الدراسة، وإلى جانب ذلك تم اعتماد البحث التحليلي الميداني، لغرض جمع المعلومات عبر المسح الثامل واستخدام الاستبانة في ذلك، وتحليلها من خلال استخدام (SPS.20) والطرق الإحصائية

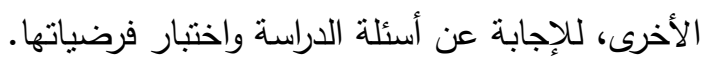

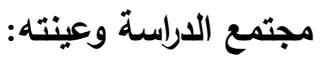
يتمنل مجتمع الدراسة في جميع المفوضين والمديرين ومساعدي المديرين ورؤساء الاقسام ورؤساء

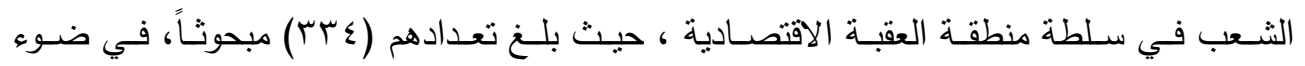




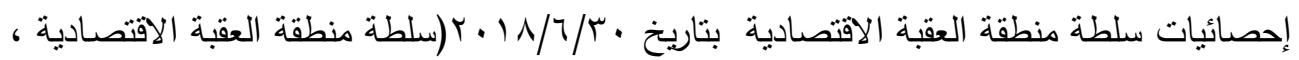

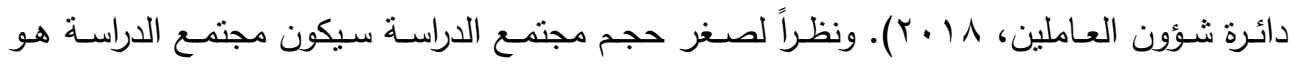
عينتها، وقد نم توزيع (ع سب) استبانه على عينة الدراسة، وتم توزيع الاستبانات على جميع مفردات

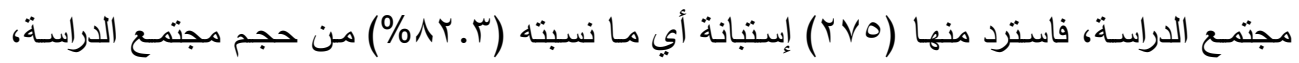

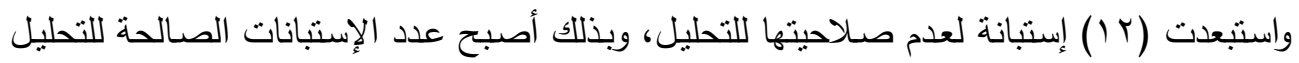

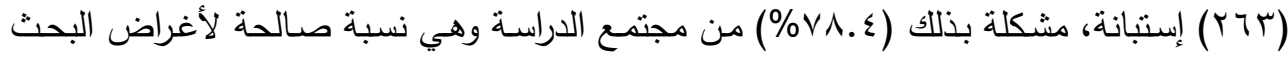
العلمي، والجدول رقم( ( ) يبين خصائص عينة الدراسة.

جدول رقم (1)

توزيع أفراد مجتمع الدراسة حسب المتغيرات (النوع الاجتماعي ،المؤهل التعليمي، العمر، الخبرة (الوظيفية، المسمى الوظيفي).

\begin{tabular}{|c|c|c|c|}
\hline النسبة & العدد الع & المستوى & المتغير \\
\hline$\% \vee Y .7$ & 191 & 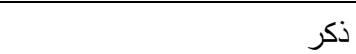 & \multirow{3}{*}{ النوع الاجتماعي } \\
\hline$\%$ \%V. & VY & أنتى & \\
\hline$\% 1 \ldots$ & אוז & المجموع & \\
\hline$\% \backslash r . r$ & rt & دبلوم متوسط فما دون & \multirow{5}{*}{ المؤهل التعليمي } \\
\hline$\% \vee \cdot . \vee$ & 1117 & بكالوريوس & \\
\hline$\% 9.9$ & r7 & ماجستير & \\
\hline$\% \vee . r$ & 19 & دكتوراه & \\
\hline$\% 1 \ldots$ & אוT & 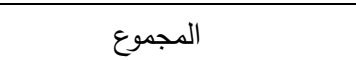 & \\
\hline$\%\urcorner . \wedge$ & 18 & ه باقل من هY سنه & \multirow{6}{*}{ 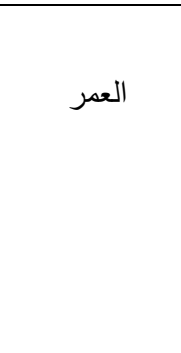 } \\
\hline rq. & 103 & من هץ الى اقل من هب سنة & \\
\hline$\%$ \%r.A & 60 & من هب سنة الى اقل من 0کسنه & \\
\hline$\% r \cdot .0$ & 54 & من 0 ؛ الى اقل من 00 سنة & \\
\hline$\% 1 \cdot . V$ & 28 & 0000 & \\
\hline$\% 1 \ldots$ & אוT & المجموع & \\
\hline$\% 1 \cdot . r$ & 27 & هنوات فأقل & \multirow[t]{5}{*}{ الخبرة الوظيفية } \\
\hline$\% \leqslant \cdot r$ & 106 & من 0-اقل من · ا سنوات & \\
\hline$\%$ \%१.r & 77 & من · 1 - اقل من 10 سنه & \\
\hline$\% r \cdot . r$ & 53 & ه اسنة فأكثر & \\
\hline$\% 1 \ldots$ & אוז & المجموع & \\
\hline
\end{tabular}

المصدر : تحليل للبيانات المتحصلة من توزيع استبانة الدراسة على العاملين في سلطة منطقة العقبة الاقتصادية 
يُلاحظ مـن الجدول رقم (1) فيمـا يتعلق بـالنوع الاجتمـاعي فقد شكل الذكور مـا نسبته

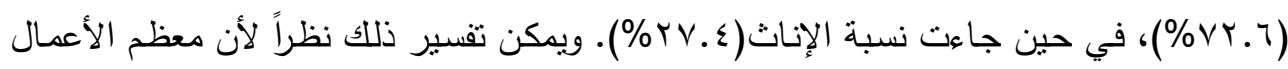

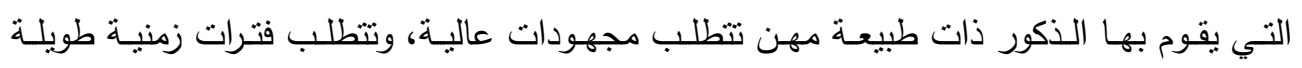
ومتصلة لإنجاز العمل وأن طبيعة معظم المهن في سلطة منطقة العقبة الاقتصادية تتطلب انجازها

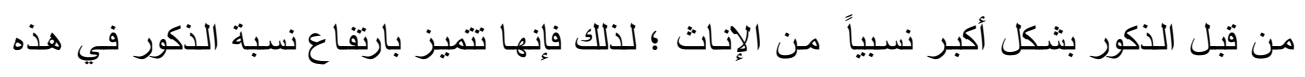
الأعمال.

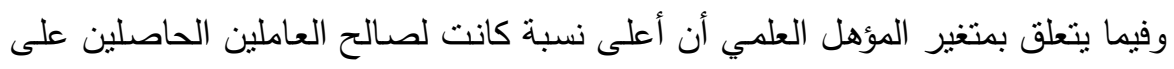

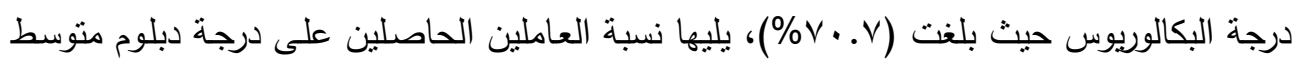

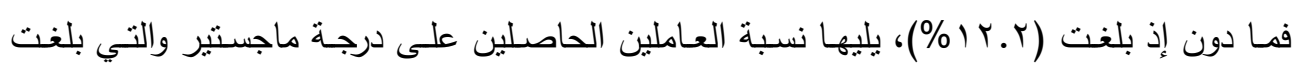

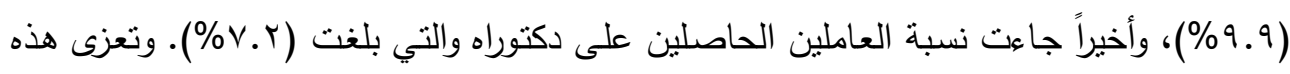
النتيجة إلى طبيعة الأعمال التي يقوم بها العاملون في سلطة منطقة العقبة الاقتصادية والتي تحتاج إلى كوادر بشرية ذات تأهيل علمي مناسب حتى تتمكن من القيام بأعمالها وتحقيق أهدافها بفاعلية.

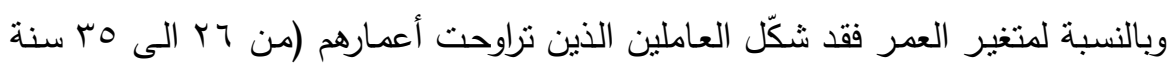

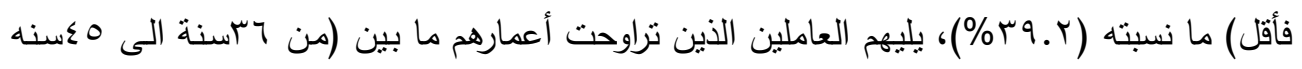

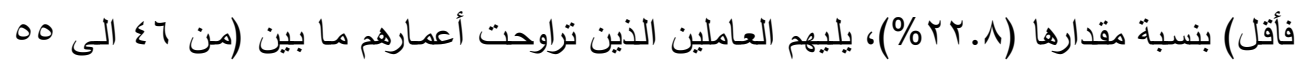

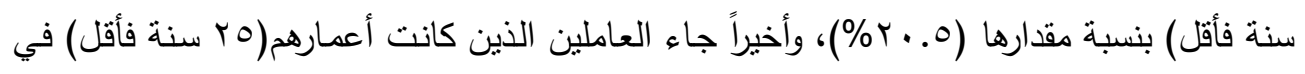

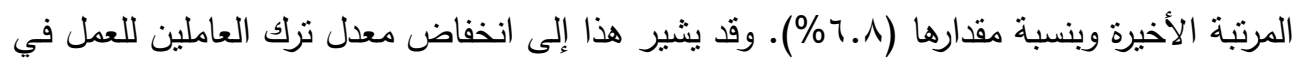

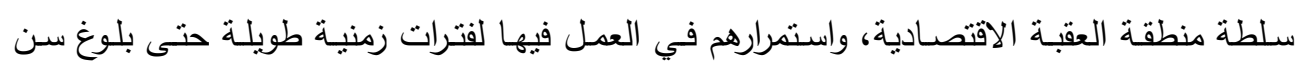
التقاعد

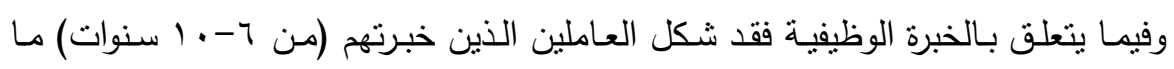

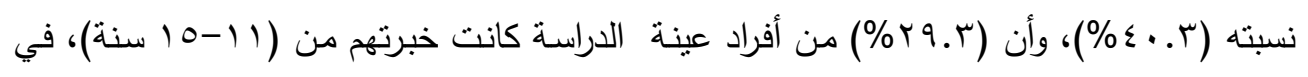

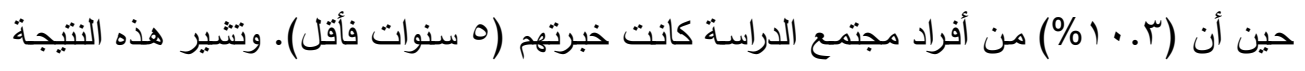

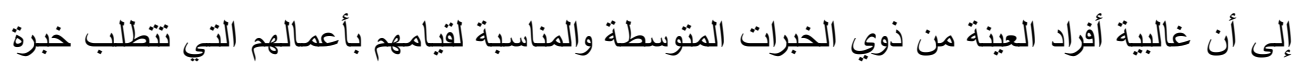
في مجال التعامل مـع المراجعين، وتحقيق أهداف سلطة منطقة العقبة الاقتصادية بكفاءة وفاعلية.

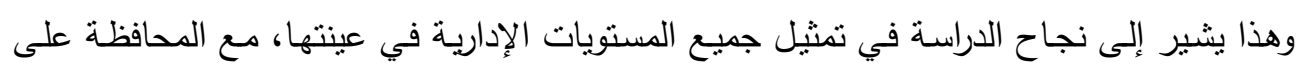

خصائصهم الوظيفية.

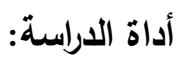

تمّ تطوير استبانة الدراسة اعتماداً على الإطار النظريّ والدراسات السابقة في الموضوع، وقد تكوّنت الاستبانة من ثناثة أجزاء: 
الجززء الأول: ويتضـمّن المعلومـات المعبّرة عن خصـائص عيّنة الدراسـة، طبقاً للمتغيّرات الديمغرافية وهي (النوع الاجتماعي، المؤهل التعليمي، والعمر، والخبرة الوظيفية، والمسمى الوظيفي). الجزء الثاني: ويتضمن هذا الجزء فقرات تغطي متغير الدراسة المستقل (التوجه الريادي)

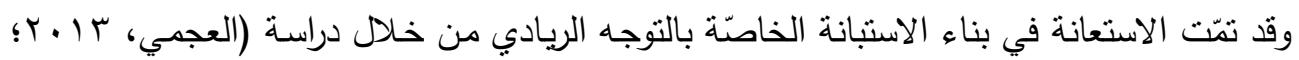

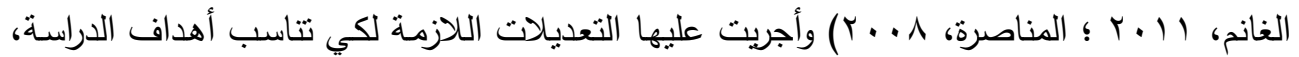

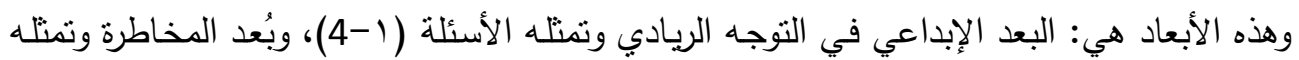

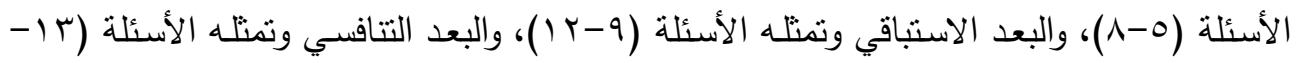

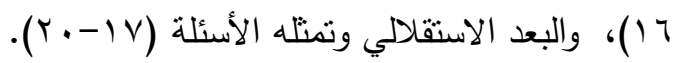

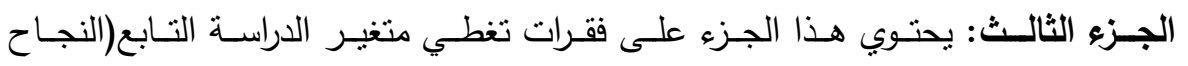
الاستراتيجي) وتم الاسترشاد في بناء فقرات هذا المتغير بدراسة كل من(التميمي، والخشالي، 10 • ب؛ Sara.\&Aghashahib, 2016 (وهذه الأبعاد هي : صياغة إستراتيجية واضحة وتمثله الفقرات

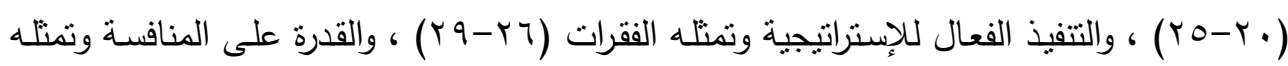

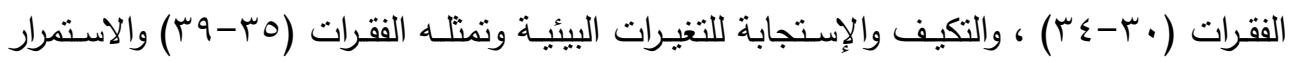

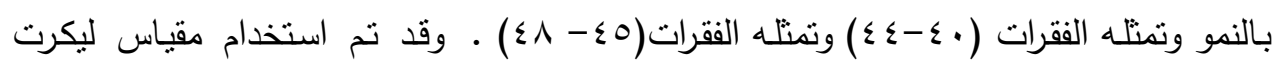
الخماسي (Likert) لقياس إجابات المبحوثين ، الذي يحتسب أوزان فقراتها على النحو التالي : (تتطبق دائماً وتمثل ه درجات)، (تتطبق غالباً وتمنل ع درجات)، (تتطبق أحياناً وتمثل سدرجات)، (تتطبق نادراً وتمنل درجنين)، (لا تتطبق إطلاقاً وتمثل درجة واحدة).

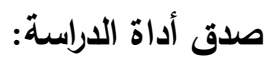

لقد تم عرض الاستبانة على (^) محكمين من المختصين في المجال الإداري وأساتذة الإدارة في الجامعات الأردنية للتأكد من صدق الاستبانة وقد نم مراعاة آرائهم والأخذ بملحوظاتهم وتم إعادين الإدادي صياغة بعض الفقرات وإجراء التعديلات المطلوبة، بشكل دقيق يحقق التوازن في مضامين الاستبانة

وفقراتها.

ثبات أداة الدراسة: - ماتهات جرى استخراج ثبات أداة الدراسة باستخدام معامل كرونباخ ألفا (Cronbach's Alpha) للاتساق

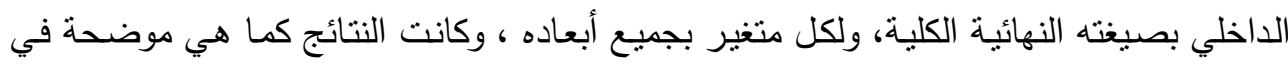

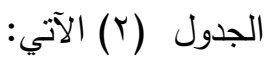




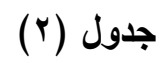

قيمة معامل كرونباخ ألفا للاتساق الداخلي لكل بُعد من أبعاد متغيرات الدراسة.

\begin{tabular}{|c|c|c|}
\hline معامل الثبات (كرونباخ ألفا) & | الأبعاد & الأداة \\
\hline$\cdot \wedge \wedge$ & البعد الإبداعي البعي & \multirow{5}{*}{ التوجه الريادي } \\
\hline$\cdot .17$ & بعد المخاطرة & \\
\hline$\cdot .19$ & البعد الاستباقي & \\
\hline$\cdot . \wedge 1$ & البعد التنافسي & \\
\hline$\cdot . \wedge \Gamma$ & البعد الاستقلالي & \\
\hline$\cdot . \wedge \mathrm{V}$ & صياغة إستر اتيجية و اضحة & \multirow{5}{*}{ النجاح الإستراتيجي } \\
\hline$\cdot .19$ & التنفيذ الفعال للإستر اتيجية & \\
\hline .9 & القدرة على المنافسة & \\
\hline$\cdot . \mathrm{AV}$ & التكيف و الإستجابة للتغير ات الييئية & \\
\hline$\cdot . \wedge r$ & الاستمر ار بالنمو & \\
\hline
\end{tabular}

الصصدر : تحليل للبيانات المتحصلة من توزيع استبانة الدراسة على العاملين في سلطة منطقة العقبة الاقتصادية

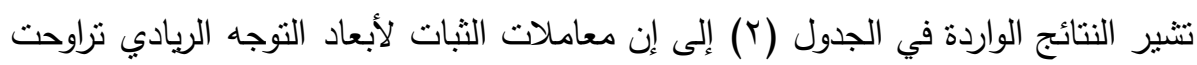

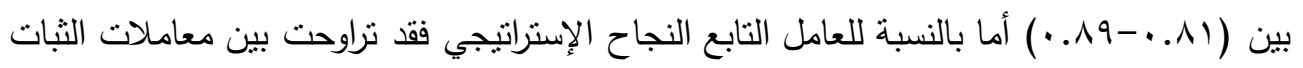

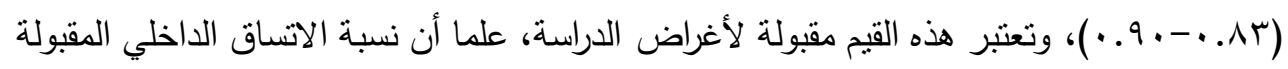
هي( • V. • فما فوق). المعالجة الإحصائية:

Statistical ) (SPSS.20) تستخدم الدراسـة برنـامج الرزم الإحصـائية للعلوم الاجتماعيـة (Package For Social Sciences فرضياتها، وفقاً للمعالجات الإحصائية الآتية:

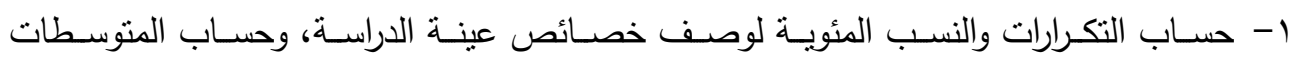
الحسابية، والانحرافات المعيارية للإجابة عن أسئلة الدراسة.

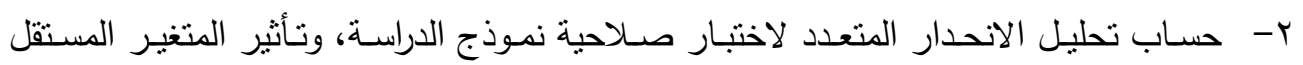
وأبعاده على المتغير التابع وأبعاده.

r- تحليل الانحدار المتعدد المتدرج لاختبار دخول المتغيرات المستقلة في معادلة التتبؤ بالمتغير التابع. ع - اختبار معامل تضخم التباين (VIF) واختبار التباين المسموح للتأكد من عدم وجود ارتباط عالٍ بين المتغيرات المستقلة.

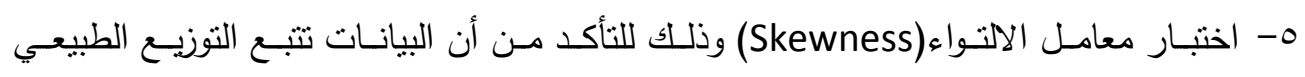
.(Normal Distributions) צ- كرونباخ ألفا (Cronbach's Alpha) لقياس الاتساق الداخلي لأبعاد الدراسة. 
من خلال إطلاع الباحث على الدراسات السابقة المتوفرة ذات الصلة المباشرة وغير المباشرة بموضوع دراسته، إلا أنه وفي حدود علمه، لم يكن هناك دراسة محلية أو عربية بحثت في موضع أثز التوجه الريادي في تحقيق النجاح الاستراتيجي في سلطة منطقة العقبة الاقتصادية، حيث تم العثور على دراسات بحثت في أحد متغيرات الدراسة إما المتغير المستقل أو المتغير التابع، ونم تلخيصها على النحو الآتي:

\begin{tabular}{|c|c|c|c|}
\hline أهم النتائج & المنهجية & هدف الدراسة & الباحث \\
\hline 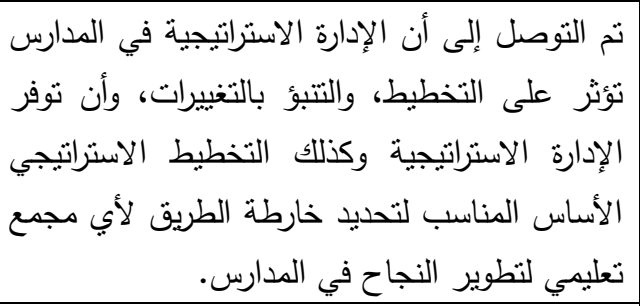 & في العاصمة الايرانية طهران (ع الداسة من مديراً & إدارة المدارس على عوامل النجاح الاسنراتيجي في & $\begin{array}{l}\text { Amoli and ) } \\
\text { Aghashahi, } \\
\quad(2016\end{array}$ \\
\hline 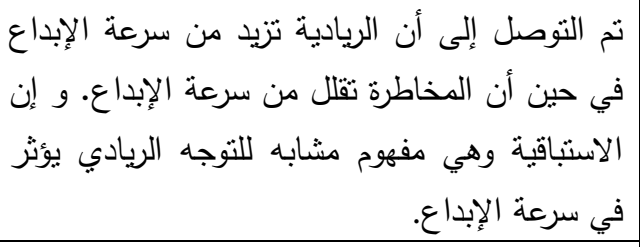 & مشروعاً جديداً في الصينة الدراسة من(153) & تطوير نموذج نظري لدراسة كيف تؤثر سرعة الإبداع التي تتوسط العلاقة بين التوجه الريادي & $\begin{array}{c}\text { Peng \& ) } \\
\text { Michael \& } \\
\text { (Xiaofeng, 2016 }\end{array}$ \\
\hline 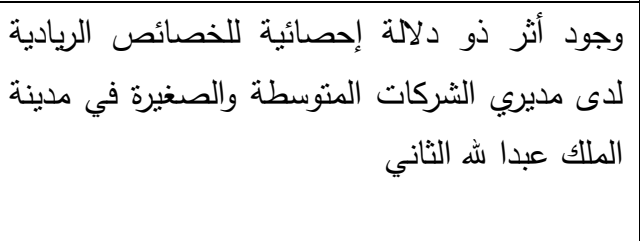 & أو من ينوبت عينة الدراسة من (1 ( ) مديراً & 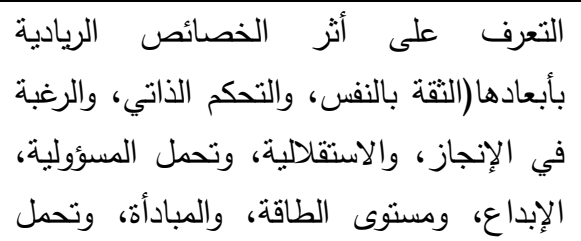 & 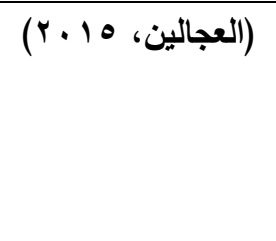 \\
\hline
\end{tabular}




\begin{tabular}{|c|c|c|c|}
\hline & & والصغيرة في تحقيق الفاعلية التتظيمية المديرة المتوسطة & \\
\hline 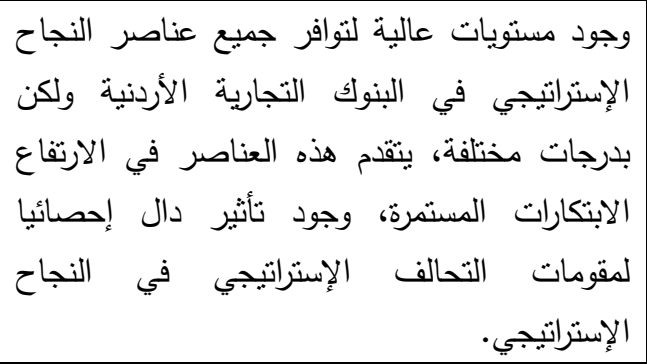 & 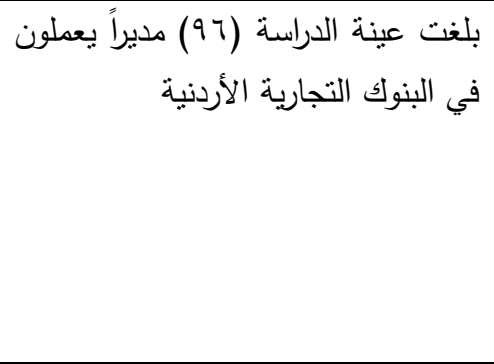 & 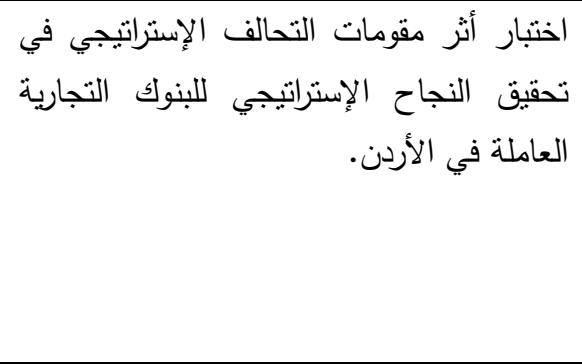 & (التميمي والخشالي، \\
\hline 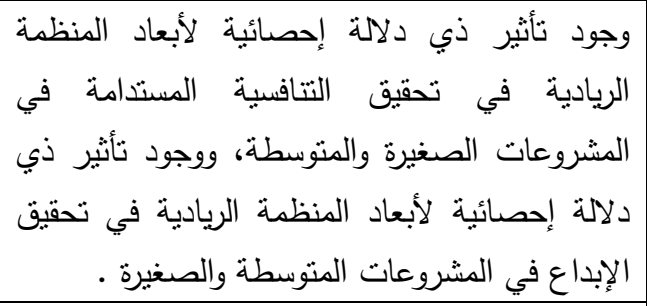 & صنكونت عينة الدراسة من (107) شركة & 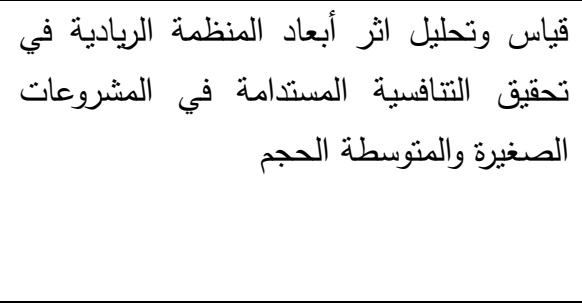 & 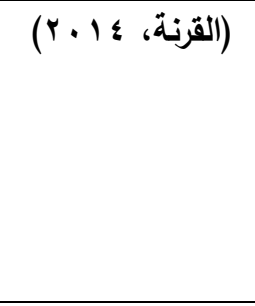 \\
\hline 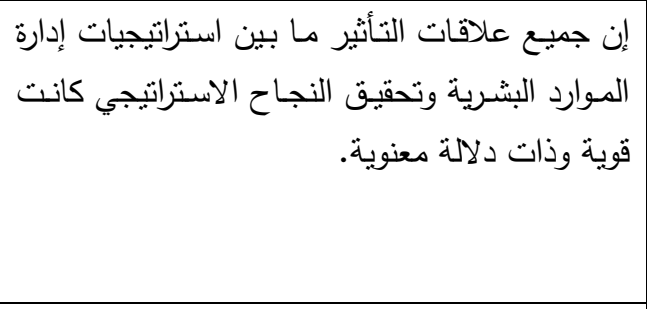 & 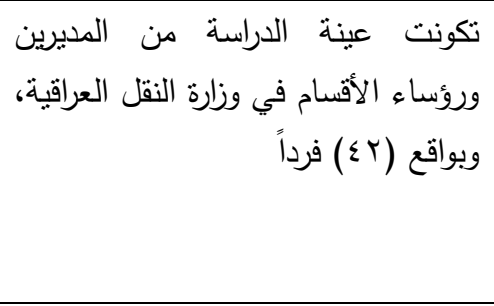 & 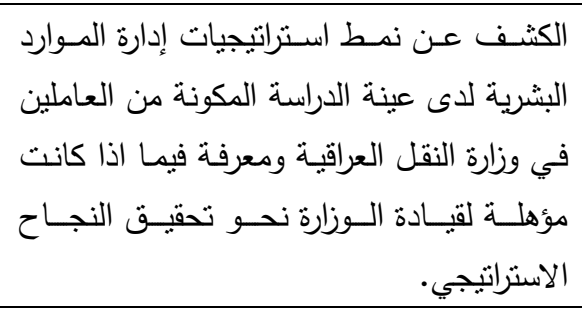 & 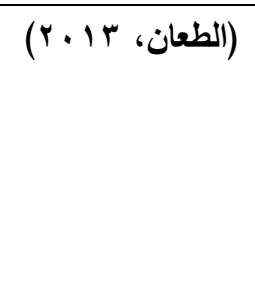 \\
\hline 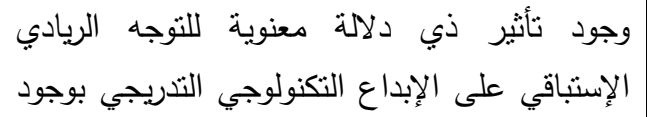 & تكونت عينة الدراسة من VV مفردة & الإبداع التكنولوجي أثر التوجه الريادي الاسنباقي إلى & وآخرون، r ا • ب) \\
\hline
\end{tabular}




\begin{tabular}{|c|c|c|c|}
\hline المرونة الإستراتيجية & & الإلنتراتيجية المنضمنة مرونة الملكية الأردنية بوجود المرونة & \\
\hline 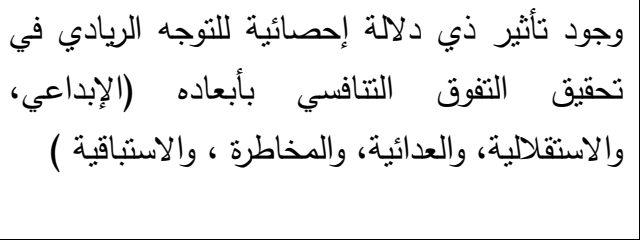 & تكونت عينة الدراسة من (1 • ( ) مفردة & 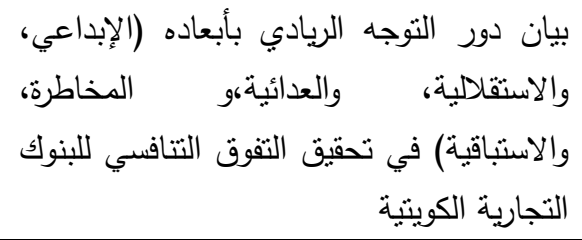 & 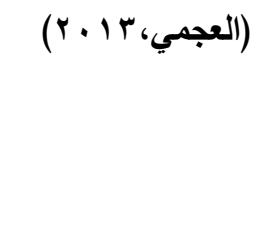 \\
\hline 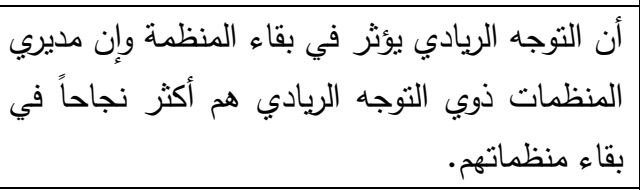 & 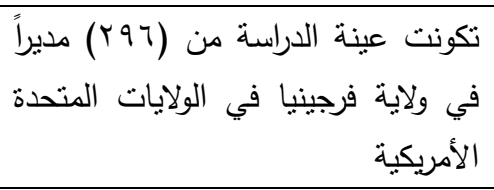 & كناءة المديرين ذي التوجه الريادي بقاء المنظمة الريادي عن غاختبار & $\begin{array}{c}\text { (Mousa \& Wales } \\
\text {, 2012) }\end{array}$ \\
\hline 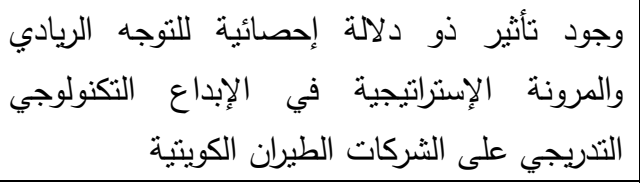 & تكونت عينة الدراسة من (V^) مفردة & في بيان أنز النوجه الريادي والمرونة الإستراتيجية & 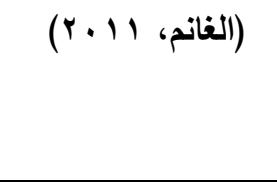 \\
\hline 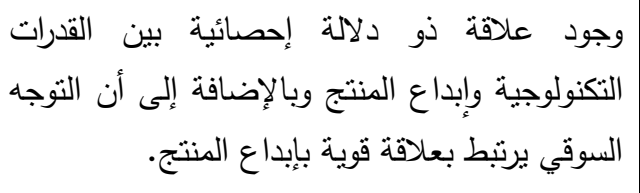 & 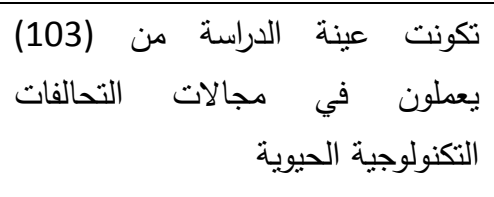 & 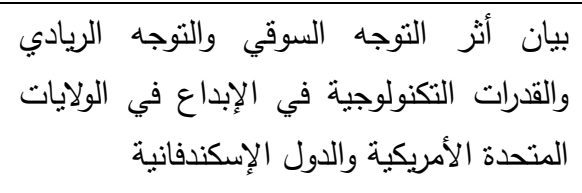 & ( Renko, 2010) \\
\hline 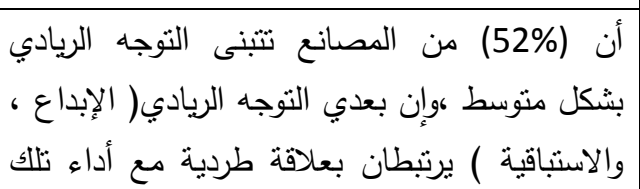 & منكونت عينة الدراسة من(25) مصنعاً & 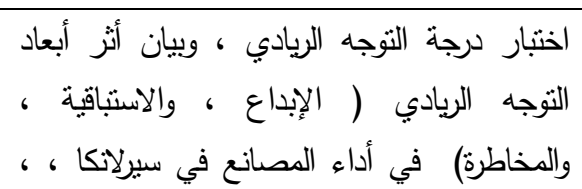 & $\begin{array}{c}\text { ( Fairoz,et.al, } \\
2010 \text { ) }\end{array}$ \\
\hline
\end{tabular}




\begin{tabular}{|c|c|c|c|}
\hline 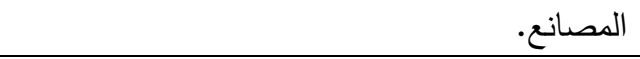 & & وكانت المقابلات هي الأداة الرئيسة لجمع الييانات & \\
\hline 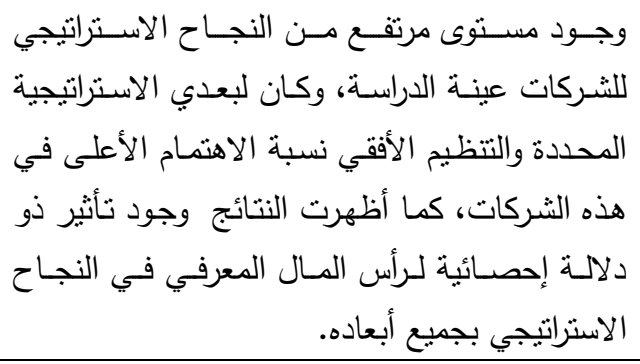 & مديراً في شركات الاتصالات الأردنية عـوائية وبواقع (ه) & أسباب النجاح الاستراتيجي. أنـر رأس الهـال المعرفي في & 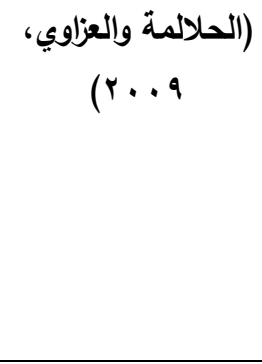 \\
\hline 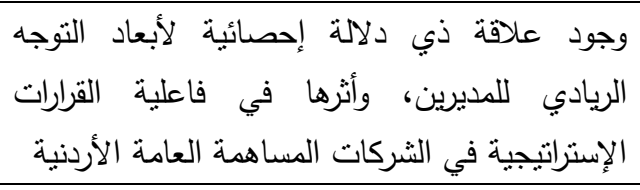 & 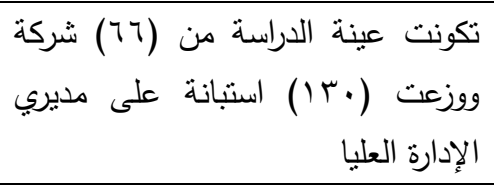 & 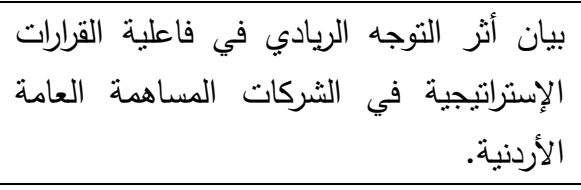 & 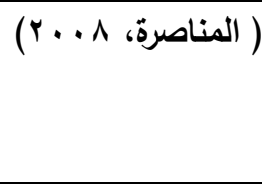 \\
\hline 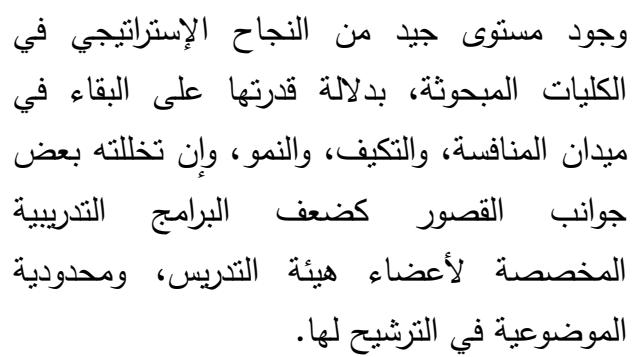 & 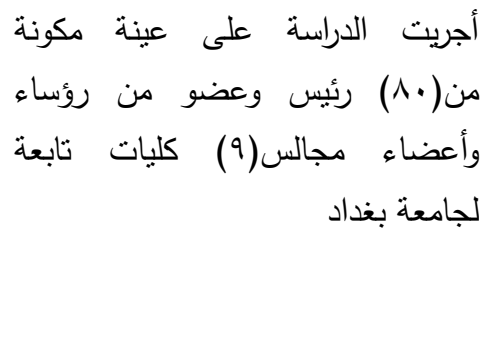 & 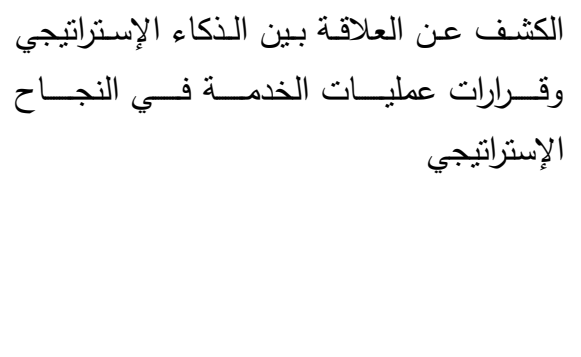 & 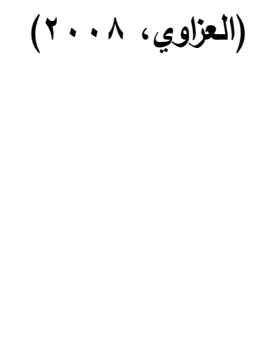 \\
\hline
\end{tabular}




\section{ما يميز هذه الدراسة عن الدراسات السابقة:}

ركّزت معظم الدراسات العربية والأجنبية على دراسة التوجه الريادي في منظمات وبيئة الأنات مختلفة، وركزّ بعضها الآخر منها على أثز الخصائص الريادية في الفاعلية التظظيمية كدراسة (العجالين،

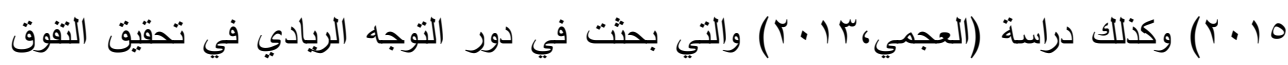

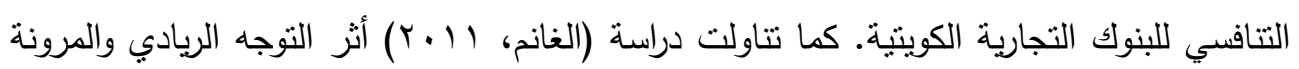

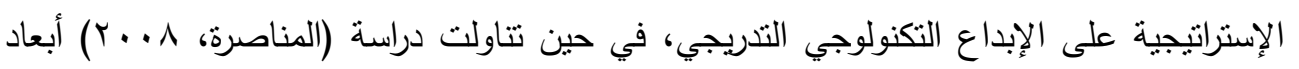

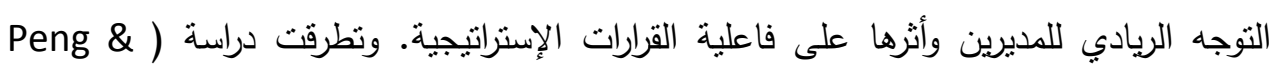

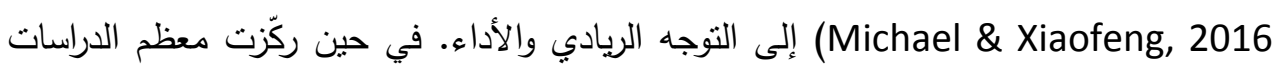

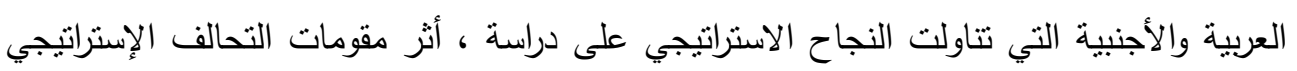

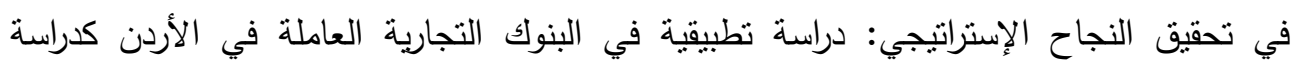

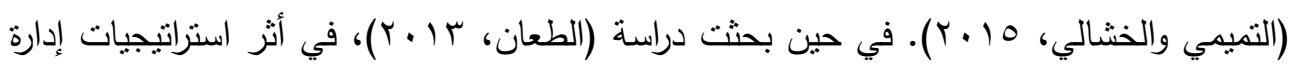
الموارد البشرية في تحقيق النجاح الاستراتيجي: دراسة ميدانية في وزارة النقل العراقية". وتطرقت

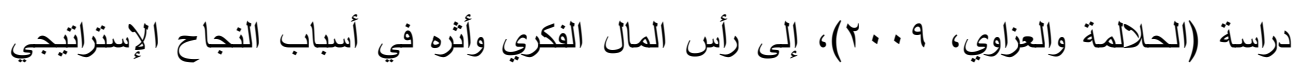

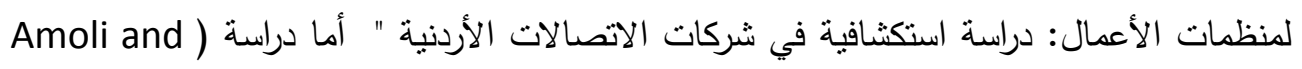

Aghashahi, 2016 )، فهدفت إلى التعرف على عوامل النجاح الاستراتيجي في إدارة المدارس.

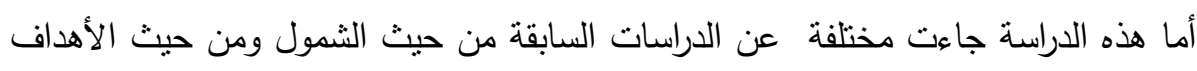
: فقد تتوعت الاتجاهات البحنية للدراسات السابقة ، التي هدفت إلى بيان أهمية ودور التوجه الريادي وخصائص الريادية على الأداء والإبداع، في حين تتاولت هذه الدراسة موضوع أثز التوجه لهابه الريادي للمديرين ( الإبداع، والاستباقية، والاستقلالية، والمخاطرة، والتنافسية) في النجاح

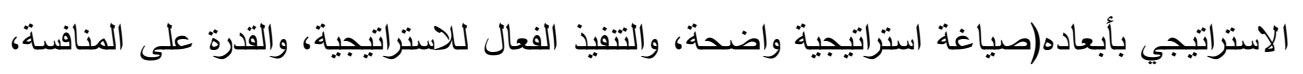
والتكيف والاستجابة للتغيرات البيئية، والاستمرار بالنمو ) في سلطة منطقة العقبة الاقتصادية . 


\section{عرض النتائج ومناقشتنها: \\ الإجابة عن أسئلة الاراسة:}

السؤال الأول: ما هي تصورات العاملين نحو التوجه الريادي للمديرين في سلطة منطقة العقبة

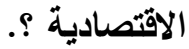

ولإجابة على هذا السؤال تم احتساب المتوسطات الحسابية والانحرافات المعيارية، لتصورات

العاملين في سلطة منطقة العقبة الاقتصادية لأبعاد التوجه الريادي للمديرين وعلى النحو الآتي:

جدول رقم (r)

المتوسطات الحسابية والانحرافات المعيارية لتصورات المبحوثين لأبعاد التوجه الريادي للمديرين في

سلطة منطقة العقبة الاقتصادية.

\begin{tabular}{|c|c|c|c|c|c|}
\hline للمنتوسط الحسابي & الترتيب & الانحراف & الحستوسط & أسم البعد & تسلسل \\
\hline مرتفع & 1 & .00 & $T . V \varepsilon$ & البعد الإبداعي & $1-4$ \\
\hline مرتفع مرتع & r & $.0 \mathrm{~V}$ & T.VT & بعد المخاطرة & $5-8$ \\
\hline مرتفع & $r$ &. .01 & r.71 & البعد الاستباقي & $9-12$ \\
\hline مرتفع & 0 &. $.7 r$ & $r .01$ & البعد التتافسي & $13-16$ \\
\hline مرتفع & $\varepsilon$ & .09 & T.7. & البعد الاستقلالي & $17-20$ \\
\hline مرتفع & - & $.0 \%$ & 1.70 & المنتوسط الكلي & $20-1$ \\
\hline
\end{tabular}

الصصدر : تحليل للبيانات المتحصلة من توزيع استبانة الدراسة على العاملين في سلطة منطقة العقبة الاقتصادية

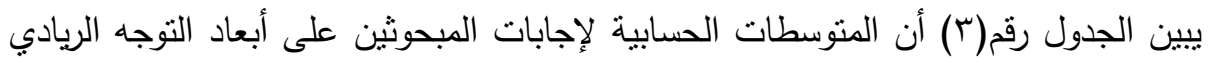

للمديرين في سلطة منطقة العقبة الاقتصادية (البعد الإبداعي، بعد المخاطرة، البعد الاستباقي، البعد

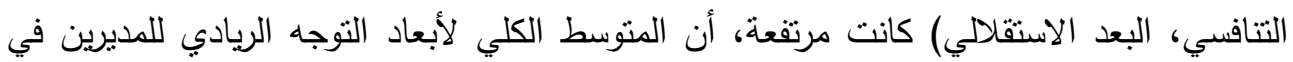

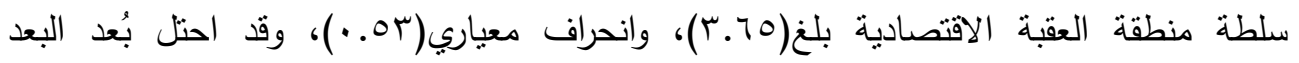

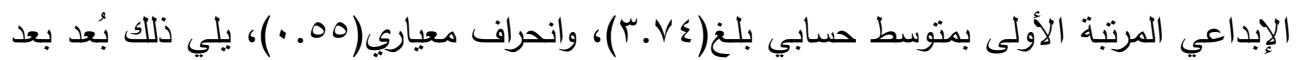

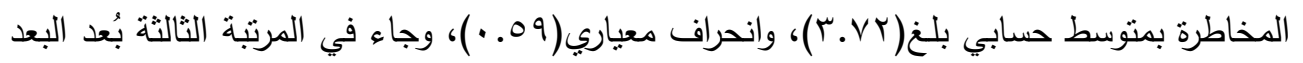

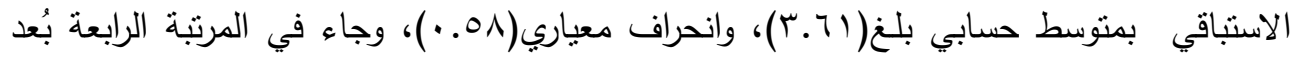

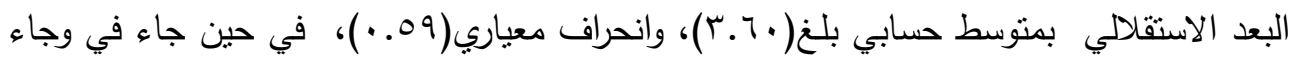

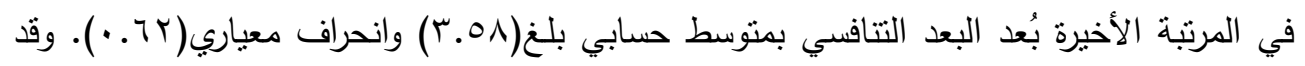

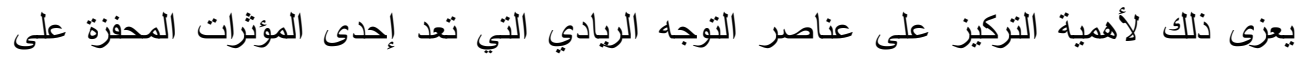
النجاح الاستراتيجي لتحقيق الأهداف التتظيمية، وأن البعد الإبداعي احتل المرنبة الأولى وهذه لتهيه

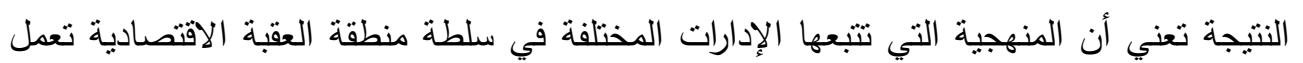


على تتجيع العاملين على تجربة وسائل جديدة مبتكرة، وتقديم الأفكار والخدمات الجديدة بطريقة منظمة ومدعمة تسهم في تحقيق أهداف العمل، يلي ذلك بُعد المخاطرة وتعد هذه الإستراتيجية بمنزلة نظام يحوي المبادرات والمناهج والأدوات الموجهة لإيجاد تدفق مثالي للمعارف لتحقيق الأهداف التتظيمية بكفاءة وفاعلية، خلال تفويض الصلاحيات للعاملين وتحمل المسؤولية الكاملة، وتتفيذ المشاريع الضرورية، والوصول إلى التميز في أداء الأعمال، وتعزيز قدرة المنظمة على الاحتفاظ

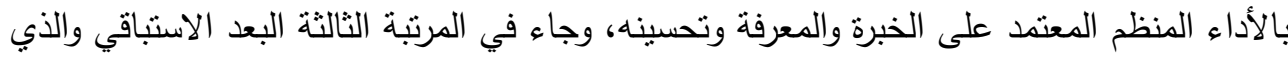
يعمل على تعزيز القدرات التنظيمية ،وتمكين الأفراد من اكتساب المهارات والمعلومات حتى يكونوا لهوبها قادرين على مواكبة التحديات الحالية والمستقبلية وتأهيلهم، بغية إحداث التغيير، والتطوير وتحسين

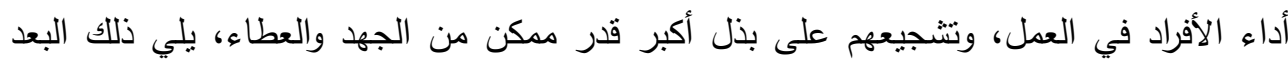
الاستقلالي وقد يعود ذلك إلى أن السلطة تطبق سياسات وبرامج نساعد في تتمية ما يمتلكه الأفراد

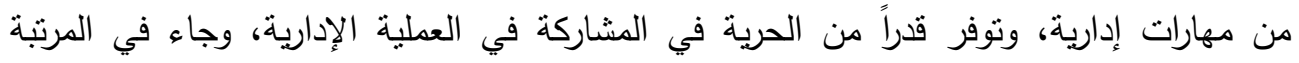

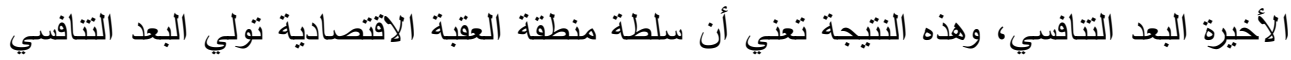

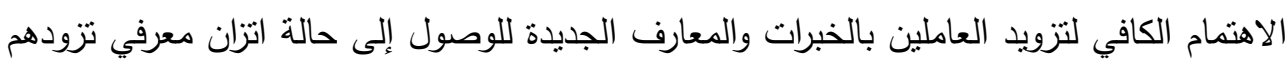

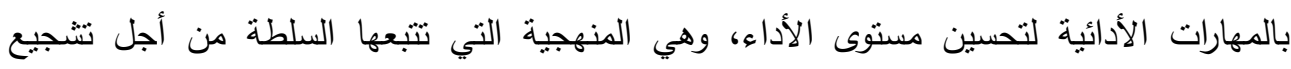

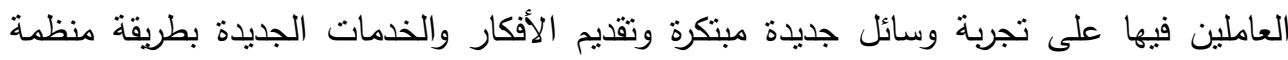
ومدعمة تسهم في تحقيق أهداف العمل. والتقت هذه النتائج مع ما جاءت به دراسة (بني حمدان وآخرون، وندان

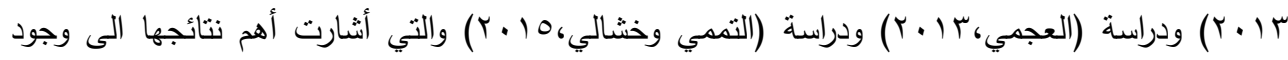

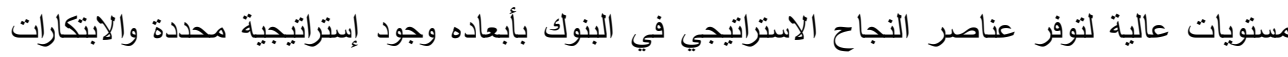

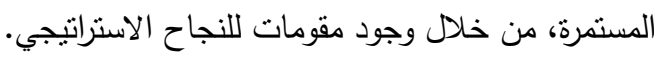

السؤال الثاني: ما هي تصورات العاملين نحو النجاح الاستراتيجي في سلطة منطقة العقبة

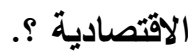

ولإجابة على هذا السؤال تم احتساب المتوسطات الحسابية والانحرافات المعيارية، لتصورات العاملين في سلطة منطقة العقبة الاقتصادية لأبعاد النجاح الاستراتيجي وعلى النحو الآتي: 
جدول رقم (飞)

المتوسطات الحسابية والانحرافات المعيارية لتصورات المبحوثين لأبعاد النجاح الاستراتيجي في

سلطة منطقة العقبة الاقتصادية.

\begin{tabular}{|c|c|c|c|c|c|}
\hline مستوى الفقرة & التزتيب & الانحراف & الحسابي & أسم البعد & تسلسل \\
\hline مرتفع & r & $\because .74$ & T.70 & صياغة استراتيجية واضحة & ro-r) \\
\hline 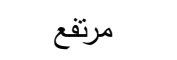 & $r$ & .79 & r.7) & التتفيذ الفعال للاستراتيجية & $r q-Y\urcorner$ \\
\hline 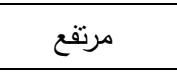 & 0 & $\cdot . V 1$ & $r .07$ & القدرة على المنافسة & $r \leqslant-r$. \\
\hline 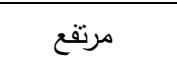 & $\varepsilon$ & $\cdot .71$ & $r .01$ & التكيف والاستجابة للتغيرات البيئية & rq-ro \\
\hline 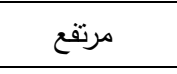 & 1 & $.7 \varepsilon$ & T.Vo & الاستمرار بالنمو & $\varepsilon \varepsilon-\varepsilon$. \\
\hline مرتفع & - & .01 & $r .7 r$ & المتوسط الكلي & $\varepsilon \varepsilon-Y)$ \\
\hline
\end{tabular}

المصدر : تحليل للبيانات المتحصلة من توزيع استبانة الدراسة على العاملين في سلطة منطقة العقبة الاقتصادية

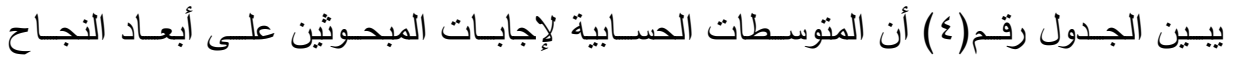

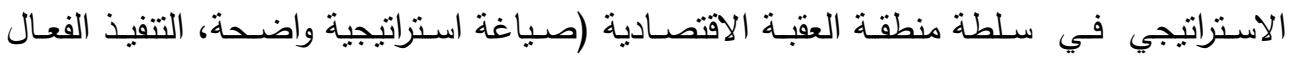

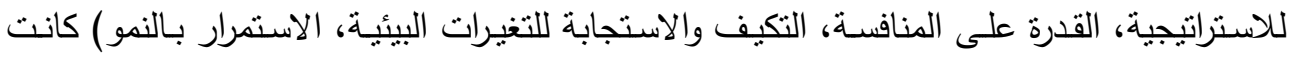

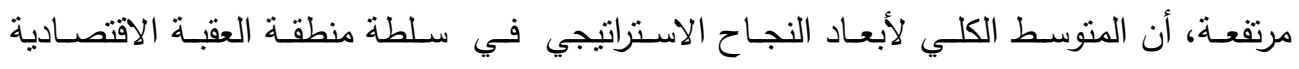

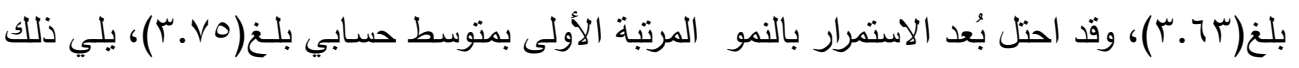

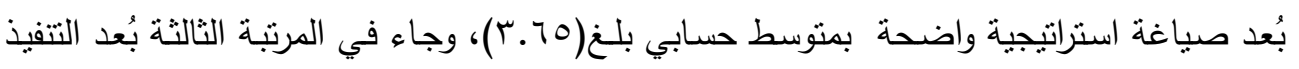

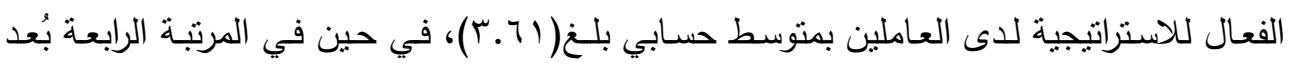

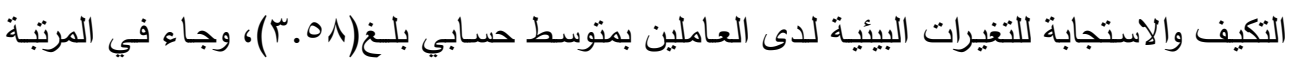

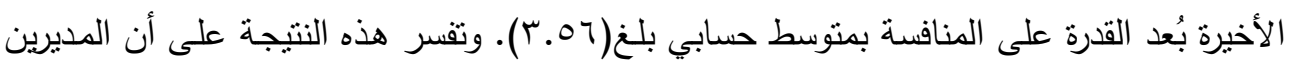

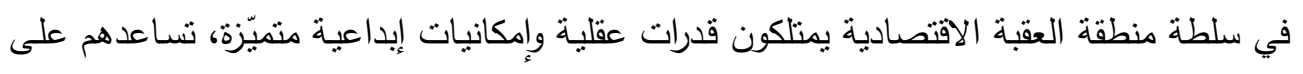

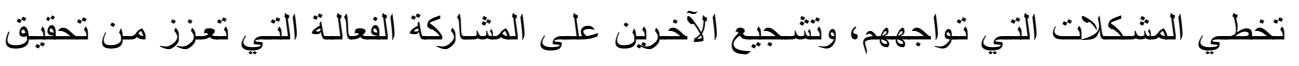

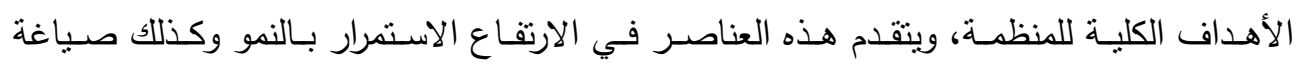
استراتيجية واضحة. ويفسر ذلك بان اهتمام سلطة منطقة العقبة الاقتصادية بهذين الجانبين يعزى الاهى

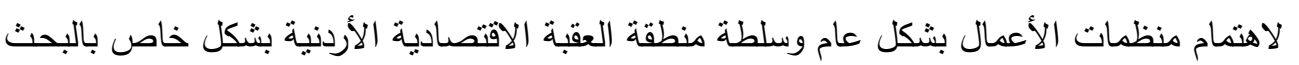

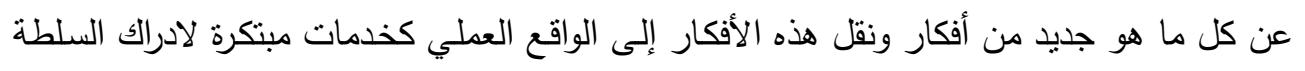

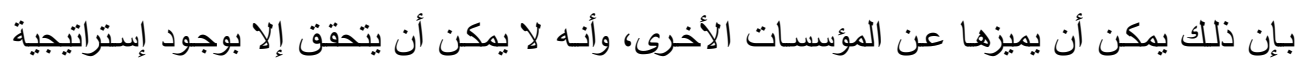

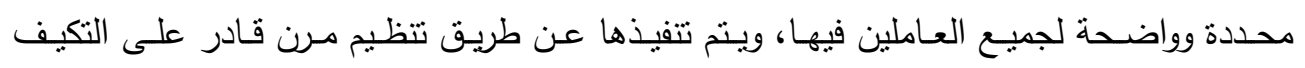




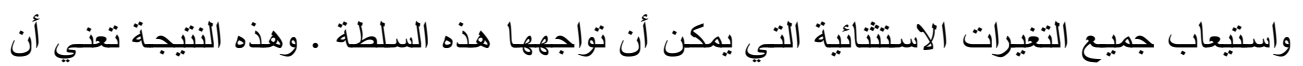
سلطة منطقة العقبة الاقتصادية نولي تحقيق أبعاد النجاح الاستراتيجي الاهنمام الكافي لتركيزها على ولى وهن

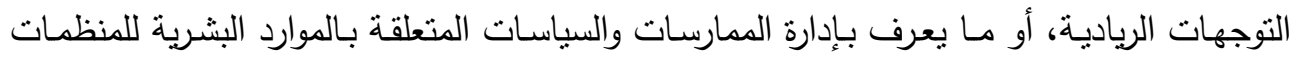
والمؤسسـات المختلفة، وتقديم تصور للرؤى المستقبلية للمنظمـة، وتصميم رسالتها وتحديد غاياتها

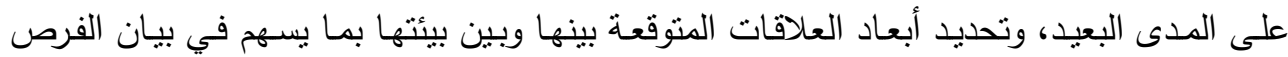
والمخاطر المحيطة بها، ونقاط القوة والضعف المميزة لها، وذللك بهدف اتخاذ القرارات الإستراتيجية المؤثرة على المدى البعيد ومراجعتها وتقويمها لتحقيق أهداف المنظمة بكفاءة وفاعلية. وربما قد تعود الدرجة المرتقعة إلى الاعتقاد بأن تحقيق أبعاد النجاح الاستراتيجي هو مسؤولية مشتركة وانعكاس

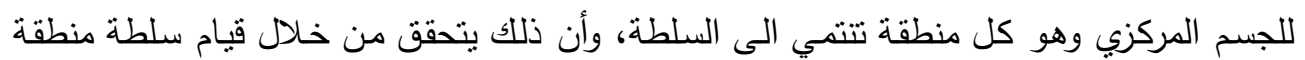

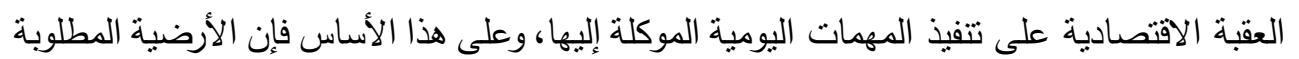
لتحقيق أبعاد النجاح الاستراتيجي يحتاج إلى إمكانات مادية وبشرية، من حيث الميزانيات وتحفيز

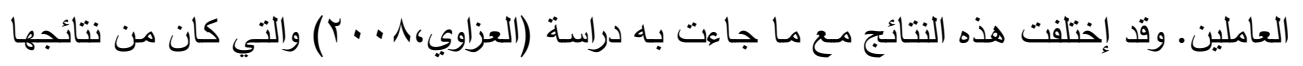

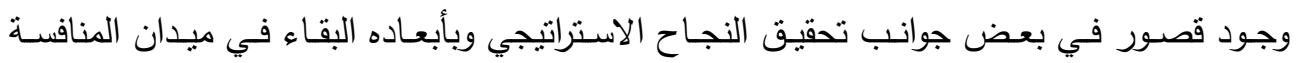
والتكيف والنمو وذللك في عدد من كليات جامعة بغداد.

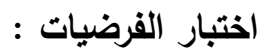

قبل تطبيق تحليل الاتحدار لاختبار الفرضيات، نم إجراء بعض الاختبارات وذلك من أجل

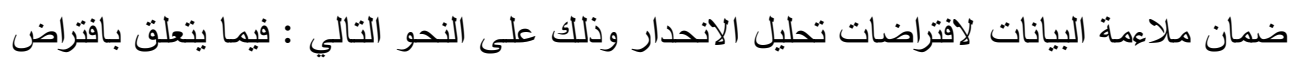

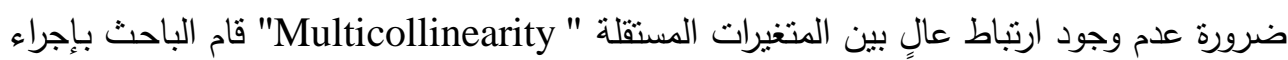
معامل تضخم التباين "Variance Inflation Factor- VIF "، واختبار التباين المسموح به " Tolerance

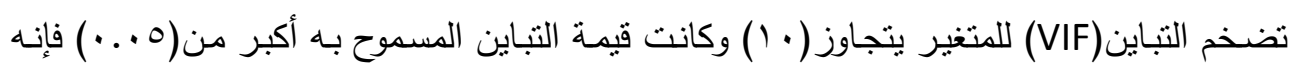

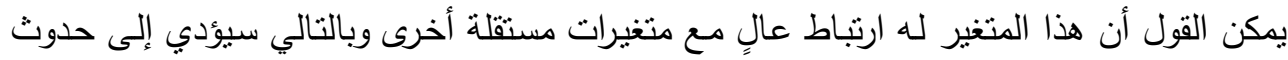

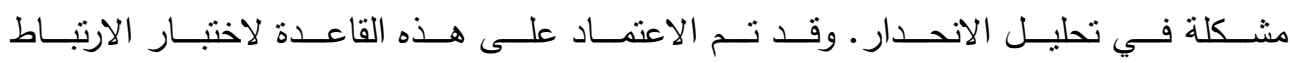
"Multicollinearity"

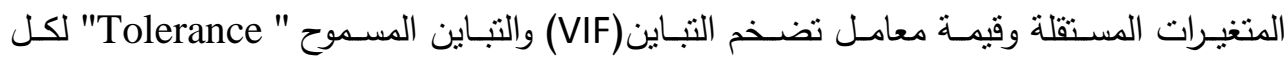

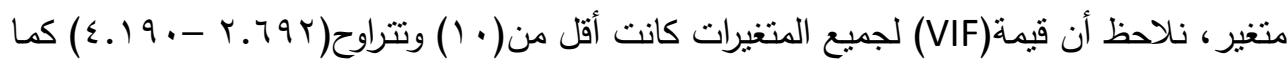

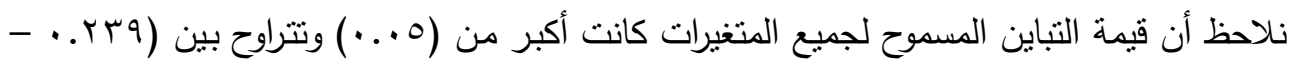
ه ـ ـ . ) ولذلك يمكن القول أنـه لا توجد مشكلة حقيقية تتعلق بوجود ارتباط عالٍ بين المتغيرات 
جدول رقم (0)

اختبار معامل تضخم التباين والتباين المسموح به ومعامل الالتواء

\begin{tabular}{|c|c|c|c|}
\hline معامل الالتواء & $\begin{array}{c}\text { معامل تقييم التباين } \\
\text { (VIF) }\end{array}$ & $\begin{array}{c}\text { التباين المسموح به } \\
\text { Tolerance }\end{array}$ & المتغيرات \\
\hline$\because Y \cdot V$ & r.79r & $\cdot r V Y$ & البعد الإبداعي \\
\hline.$Y_{1}$ & T.197 & $\cdot r \leqslant 0$ & بعد المخاطرة \\
\hline. .109 & $\varepsilon .19$. & $\cdot r r q$ & البعد الاستباقي \\
\hline$\cdot . \leqslant O V$ & T. $\leqslant 71$ & $\cdot . \varepsilon \cdot 0$ & البعد التنافسي \\
\hline.$r \backslash 1$ & r. $\vee \wedge \wedge$ &.$r 09$ & البعد الاستقلالي \\
\hline
\end{tabular}

المصدر : تحليل للبيانات المنحصلة من توزيع استبانة الدراسة على العاملين في سلطة هنطقة العقبة الاقتصادية

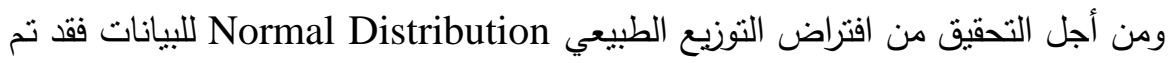

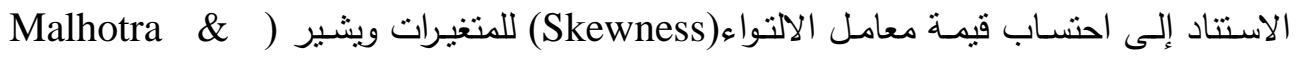
(Briks,

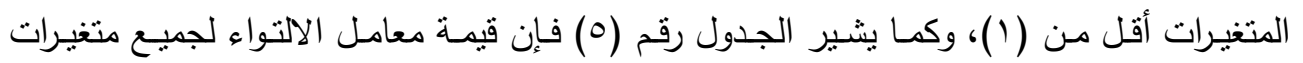
الدراسة كانت أقل من ( ( ) ولذلك يمكن القول بأنه لا نوجد مشكلة حقيقية تتعلق بالتوزيع الطبيعي لبيانات الدراسة. وسيتم التأكد من صلاحية النموذج لكل فرضية على حلى حدا. جدول رقم (7)

نتائج تحليل التباين للانحدار(Analysis Of variance) للتأكد من صلاحية النموذج لاختبار

\begin{tabular}{|c|c|c|c|}
\hline \multicolumn{4}{|c|}{ فرضيات الدراسة. } \\
\hline 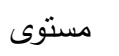 & ق قيمة F & معامل & المتغير التابع \\
\hline F دلالة F F F F & المحسوبة & R التحديد R & \\
\hline$\because \cdots$ & *IYT.YT & .080 & النجاح الاستراتيجي \\
\hline$\because \cdots$ & $* 110.94$ & .07 & صياغة استراتيجية واضحة \\
\hline$\because \cdots$ & 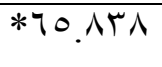 & $\cdot . \leqslant r$ & التتفيذ الفعال للاستراتيجية \\
\hline$\because \cdots$ & $* \Sigma T . \wedge T 0$ & . rro & القدرة على المنافسة \\
\hline$\because \cdots$ & $* 00.1 \mathrm{r}$ &. rVA & التكيف والاستجابة للتغيرات البيئية \\
\hline$\because \cdots$ & $* 7 \cdot .91$ & $\cdot . \varepsilon \cdot 1$ & الاستمرار بالنمو \\
\hline
\end{tabular}

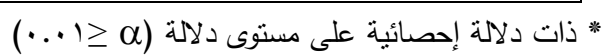
المصدر : تحليل للييانات المتحصلة من توزيع استبانة الدراسة على العاملين في سلطة منطقة العقبة الاقتصادية 


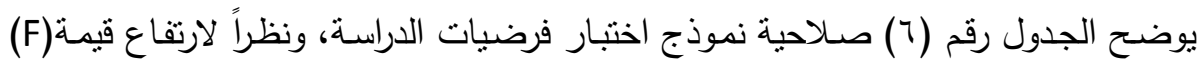

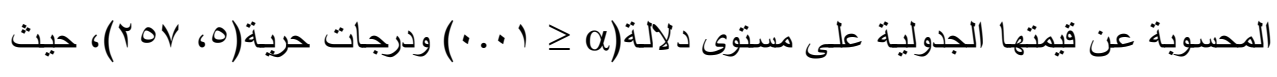

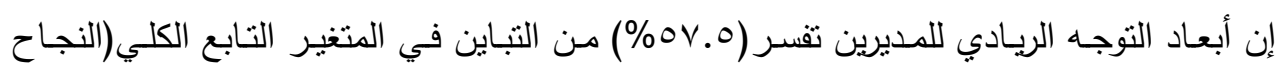

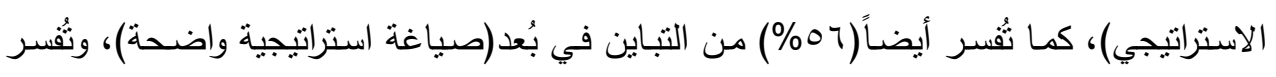
أيضاً (ץء\%) من التباين في بُعد(التفيذ الفعال للاستراتيجية)، وفسر أبعاد التوجه الريادي للمديرين

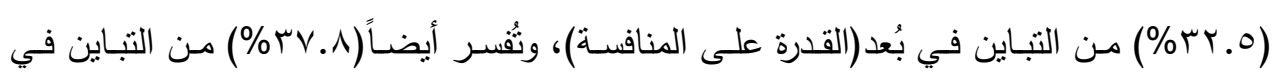

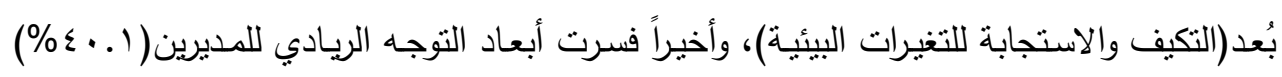

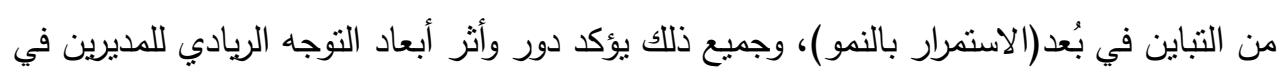

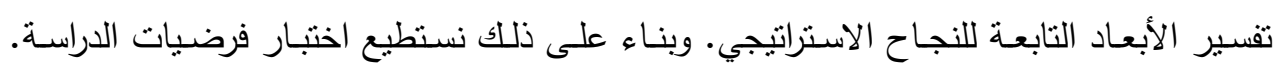

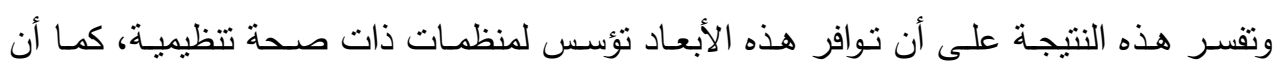

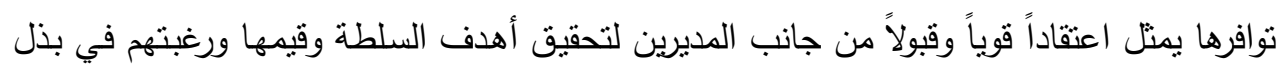

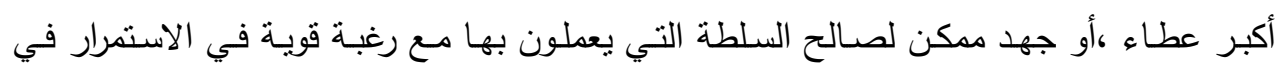
عضويتها. وقد يعود ذلك إلى أن المديرين يقومون بدور قيادي لتتسيق الجهود، وتوحيدها لتحقيق أهداف السلطة خلال فرق عمل تكون أكثر قدرة على تطوير والأعمال تحسينها. كما تفسر هذه فئه

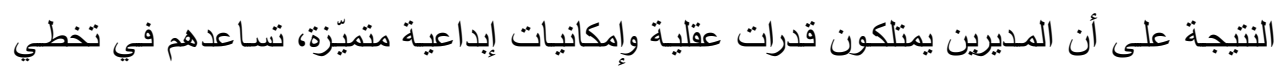

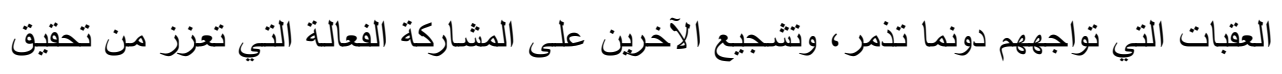
الأهداف الكلية للسلطة.

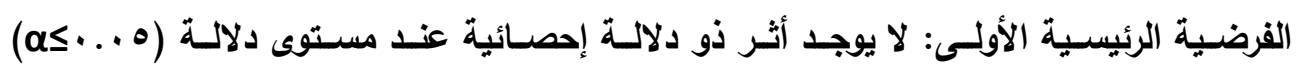

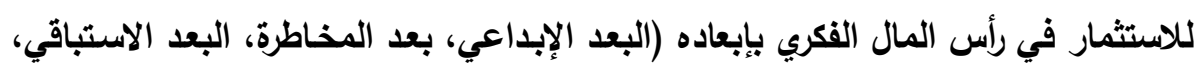

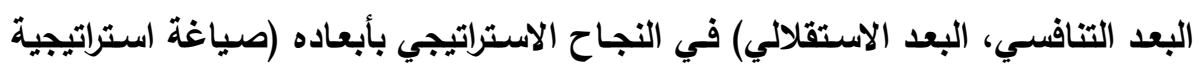

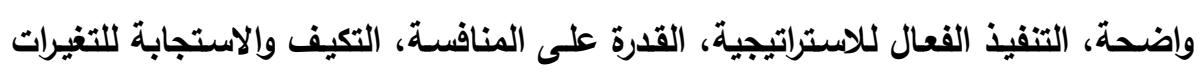
البيئية، الاستمرار بالنمو) في سلطة منطقة العقبة الاقتصادية. 


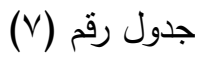

نتائج تحليل الاتحدار المتعدد لاختبار اثر التوجه الريادي للمديرين بإبعاده المختلفة في النجاح

\begin{tabular}{|c|c|c|c|c|c|}
\hline \multicolumn{6}{|c|}{ الاستراتيجي. } \\
\hline دلالة دستوى & قيمةt المحسوية & Beta & الخطأ & B & التوجه الريادي للمديرين \\
\hline$\because \cdots$ & *ะ.०Yq & $\cdot Y \cdot V$ & $\because \cdot r \Lambda$ &. .181 & البعد الإبداعي \\
\hline$\cdot r \wedge \wedge$ & **1. .70 & $\because .01$ & $\because \cdot \varepsilon$ & $\because \cdot \varepsilon \Gamma$ & بعد المخاطرة \\
\hline$\because \cdots$ & $* \varepsilon .11 \Gamma$ &. YTO & $\because \cdot \varepsilon r$ &. $.1 V \varepsilon$ & البعد الاستباقي \\
\hline$\because \cdots$ & ${ }_{*}^{*} \wedge . \wedge 9 \vee$ & $\cdot .49$. & $\because \cdot \varepsilon 1$ & צדיז. & البعد التتافسي \\
\hline$\because \cdots$ & $*_{0}^{*} . \wedge \pi \mu$ & $\cdot Y V T$ & 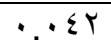 & $\cdot r \leqslant \Lambda$ & البعد الاستقلالي \\
\hline
\end{tabular}

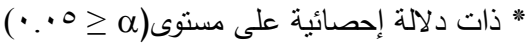

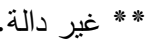

المصدر : تحليل للبيانات المتحصلة من توزيع استبانة الدراسة على العاملين في سلطة منطقة العقبة الاقتصادية

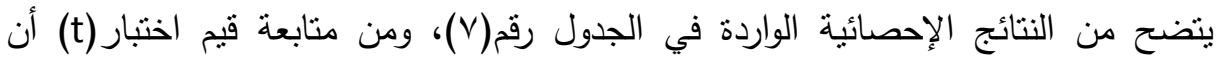
المتغيرات الفرعية التالية والمتعلقة (البعد الإبداعي، البعد الاستباقي، البعد التنافسي، البعد

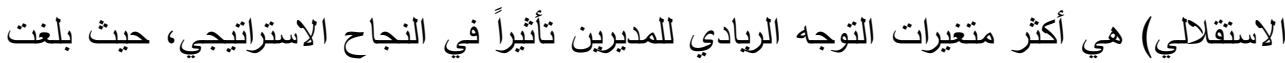

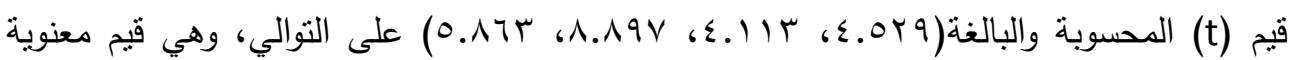

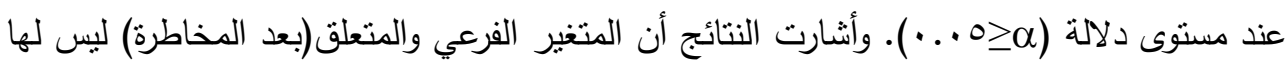
أثر في النجاح الاستراتيجي، حيث كانت قيمة(t) المحسوبة غير دالة إحصائياً عند مستوى دلالة $\cdot(\cdot .0 \geq \alpha)$

ومما سبق يقتضي ما يلي: رفض الفرضية الصفرية التي تتص على انه لا يوجد اثز هام

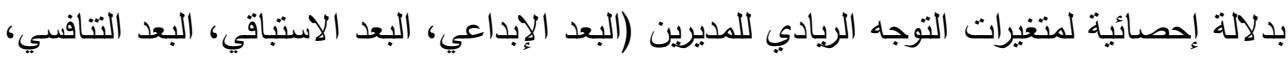

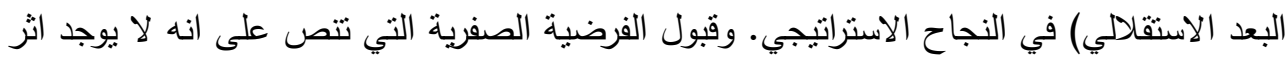

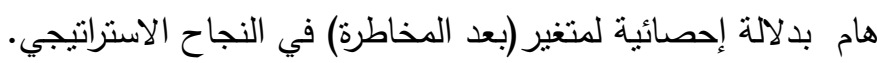
وعند إجراء تحليل الانحدار المتعدد التدريجي Stepwise Multiple Regression لتحديد أهمية كل متغير مستقل على حدة في المساهمة في النموذج الرياضي، الذي يمثل أثز التوجه الريادي للمديرين (البعد الإبداعي، بعد المخاطرة، البعد الاستباقي، البعد التتافسي، البعد الاستقاللي)

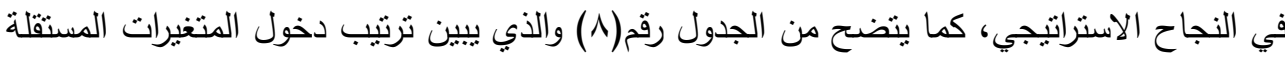

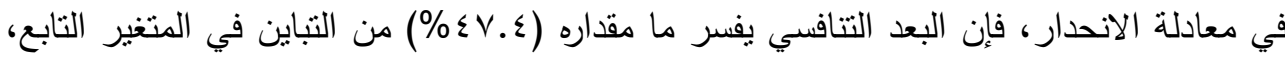
ودخل متغير البعد الاستقلالي حيث يفسر مع البعد التنافسي (9.4\%) من التباين في المتغير 


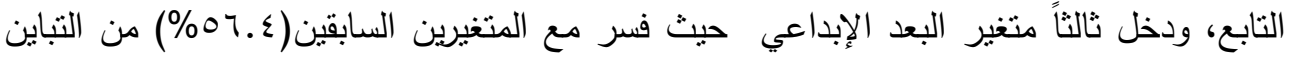

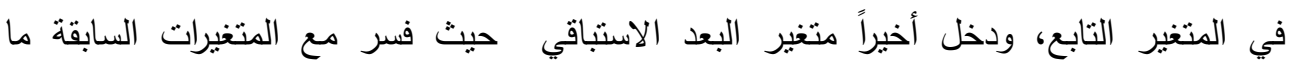
مقداره(ع.\%) من التباين في النجاح الاستراتيجي كمتغير تابع. وخرج من معادلة الانحدار

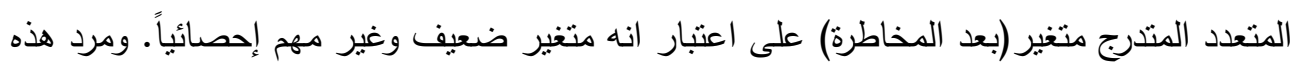

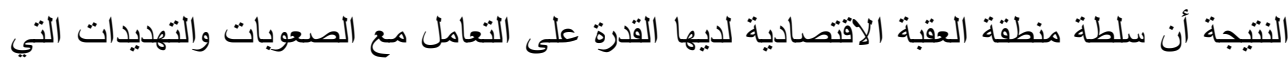

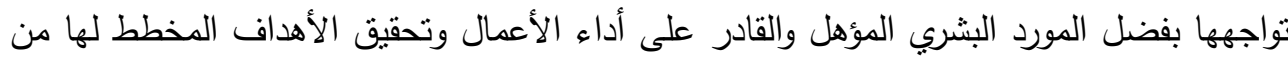
قبل الإدارة العليا. وتحقيق النجاح الإستراتيجي يسنلزم تطبيق ممارسات و سياسات تؤدي الى ادلى اداء

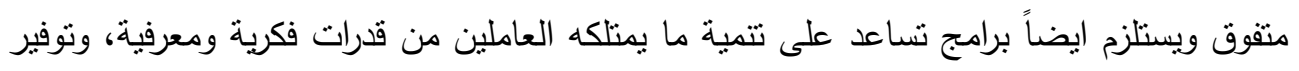

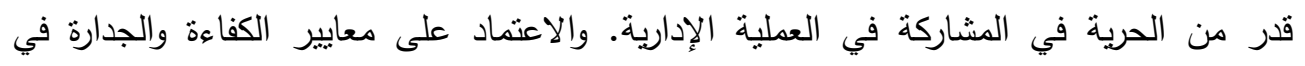

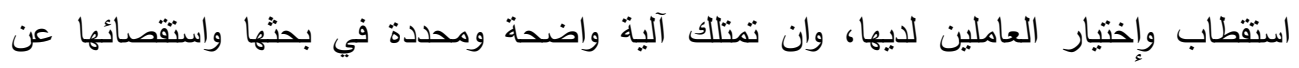
الكفاءات البشرية وإخيتارها للعمل في السلطة، مع الاهتمام بشكل أكبر في تطوير العاملين لرقابتهم

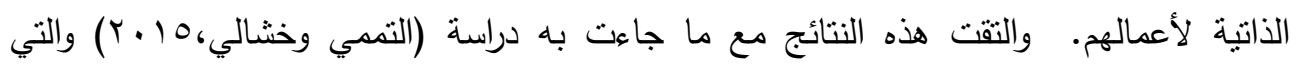
أثنارت أهم نتائجها الى وجود مستويات عالية لتوفر عناصر النجاح الاستراتيجي في البنوك بأبعاده وجود إستراتيجية محددة والابتكارات المستمرة، من خلال وجود مقومات للنجاح الاستراتيجي.

$$
\text { جدول (^) }
$$

نتائج تحليل الإنحدار المتعدد التدريجي " Stepwise Multiple Regression" للنتبؤ بالنجاح

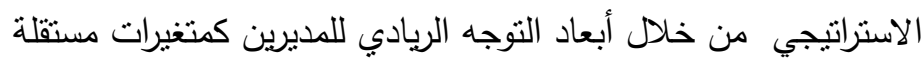

\begin{tabular}{|c|c|c|c|}
\hline مستوى دلالة t & قيمة t المحسوبة & 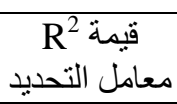 & ترتيب دخول العناصر المستقلة في \\
\hline$\because \cdots$ & ${ }^{*} \wedge . \wedge \vee 1$ & $\cdot \varepsilon V \varepsilon$ & البعد التتافسي \\
\hline$\because \cdots$ & $*_{0}^{*} . \wedge Y 1$ & .049 & البعد الاستقلالي \\
\hline$\because \cdots$ & $* \xi . \cdot Y \xi$ &. $.0 \mathrm{~V} \varepsilon$ & البعد الاستباقي \\
\hline$\because \cdots$ & $* \varepsilon .9 \wedge \varepsilon$ & $.07 \varepsilon$ & البعد الإبداعي \\
\hline
\end{tabular}

خرج من معادلة الانحدار المتعدد المتدرج متغيرات(بعد المخاطرة) المصدر : تحليل للبيانات المنحصلة من توزيع استبانة الدراسة على العاملين في سلطة منطقة العقبة الاقتصادية 


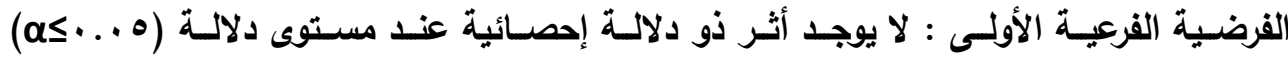
للاستثمار في رأس المال الفكري بإبعاده (البعد الإبداعي، بعد المخاطرة، البعد الاستباقي، البعد التنافسي، البعد الاستقلالي) في تحقيق صياغة استراتيجية واضحة كبعد من أبعاد النجاح الاستراتيجي.

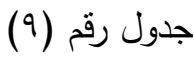

نتائج تحليل الانحدار المتعدد لاختبار اثر التوجه الريادي للمديرين بإبعاده المختلفة في صياغة استراتيجية واضحة.

\begin{tabular}{|c|c|c|c|c|c|}
\hline دلاكة t دستوى & قيمةt المحسوية & Beta & المعياري & B & التوجه الريادي للمديرين \\
\hline$\because \cdots$ & *ץ.9人7 & .114 & $\because \leqslant 0$ &. $.1 \wedge$. & البعد الإبداعي \\
\hline$\because \cdot 71$ & ${ }^{* * 1} 1 . \wedge \varphi^{\prime}$ & $\because \cdot \wedge \wedge$ & $\because \cdot \leqslant \Lambda$ & $\because \cdot \wedge \wedge$ & بعد المخاطرة \\
\hline$\because \cdot T r$ & $\star \star * .1 \leqslant r$ & $\cdot .1 Y \varepsilon$ &. .01 & $.1 \cdot 1$ & البعد الاستباقي \\
\hline$\because \cdots$ & $* \lambda_{\text {A. }} \varepsilon V \mathrm{~V}$ & $\cdot r V \Lambda$ & $\because \div 9$ &.$\leqslant 10$ & البعد التتافسي \\
\hline$\because \cdots 7$ & *Y.YOT &. $.1 \pi 1$ & $\because .0$ &. .119 & البعد الاستقلالي \\
\hline
\end{tabular}

* ذات دلالة إحصائية على مستوى(م) . . . . ** غير دالة.

الصددر : نحليل للبيانات المتحصلة من توزيع استبانة الدراسة على العاملين في سلطة منطقة العقبة الاقتصادية

يتضح من النتائج الإحصائية الواردة في الجدول رقم(9)، ومن متابعة قيم اختبار(t) أن المتغيرات الفرعية التالية والمتعلقة (البعد الإبداعي، البعد النتافسي، البعد الاستقلالي) هي أكثر

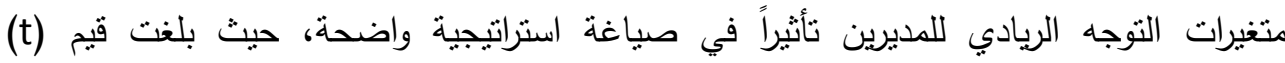

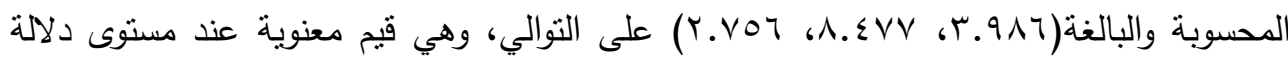

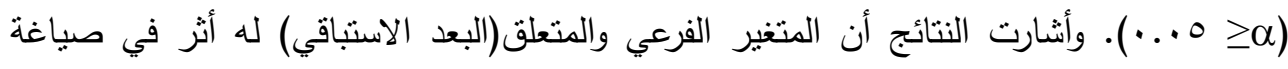

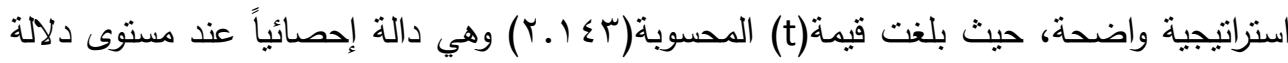

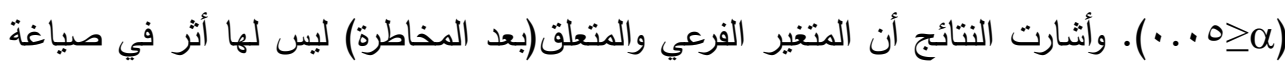
استراتيجية واضحة، حيث كانت قيمة(t) المحسوبة غير دالة إحصائياً عند مسنوى دلالة

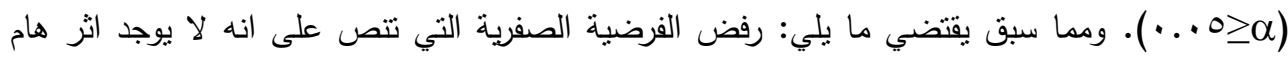

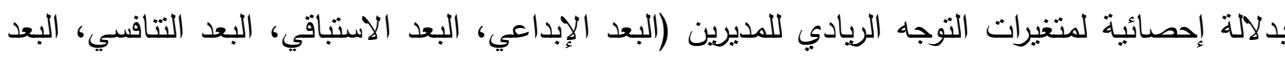

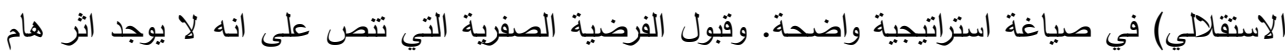
بدلالة إحصائية لمتغير (بعد المخاطرة) في صياغة استراتيجية واضحة. 
وعند إجراء تحليل الاتحدار المتعدد التنريجي Stepwise Multiple Regression لتحديد أهمية كل متغير مسنقل على حدة في المساهمة في النموذج الرياضي، الذي يمثل أثز التوجه الأنياء

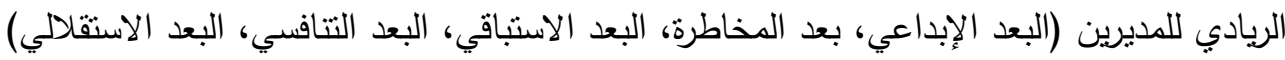
في صياغة استراتيجية واضحة، كما يتضح من الجدول رقم (· (1) والذي يبين ترتيب دخول

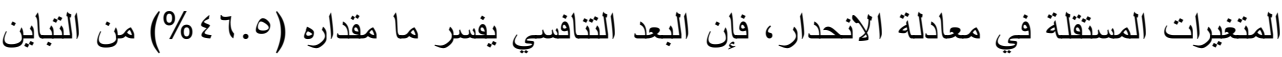

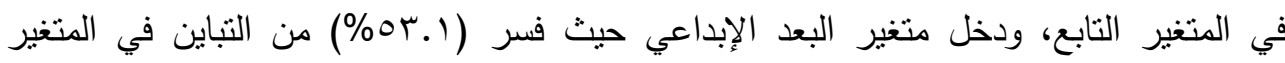

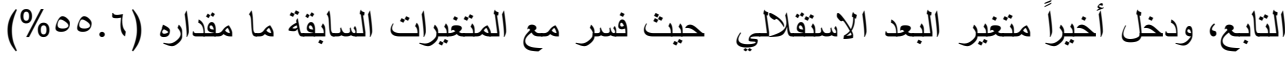
من التباين في صياغة استراتيجية واضحة كمتغير تابع. وخرج من معادلة الاتحدار المتعدد المتدرج متغيرات(بعد المخاطرة، البعد الاستباقي) على اعتبار انها متغيرات ضعيفة وخئة وغير مهمة إحصائياً.

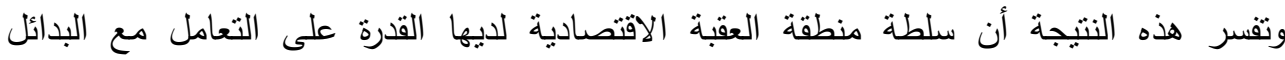
الاستراتيجية المناسبة لتنفيذ ومتابعة الاستراتيجيات، وذللك لوجود تداخل تكاملي وتشاركي بين صياغة الاستراتيجية وتتفيذها يساعد في سد النقص المنوقع في الصياغة. والتنفيذ الفعال

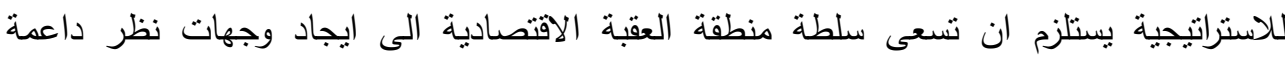

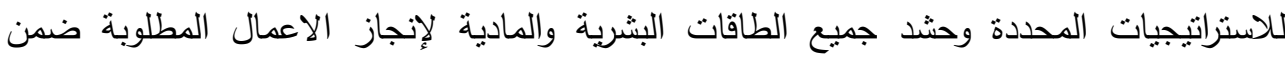
الجداول الزمنية المحددة لها وبدون اخطاء قد تؤدي الى فثل هذه الاستراتيجية من خلال نطور

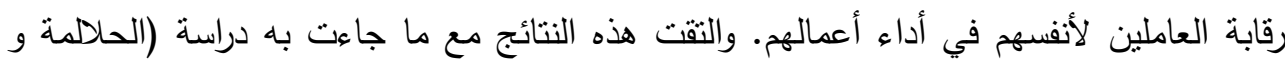

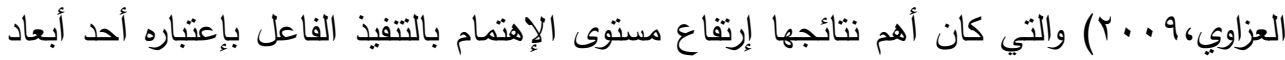

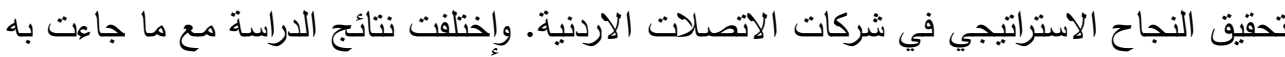

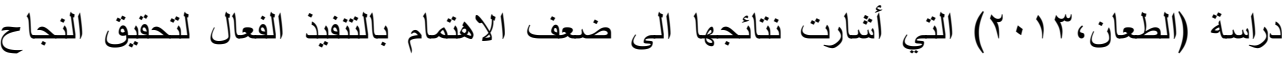

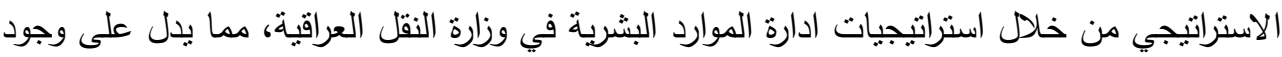
فجوه بين صياغة الاستراتيجية وبين تتفيذها.

$$
\text { جدول (·) }
$$

نتائج تحليل الإنحدار المتعدد التدريجي " Stepwise Multiple Regression" للتنبؤ صياغة استراتيجية واضحة من خلال أبعاد التوجه الريادي للمديرين كمتغيرات مستقلة

\begin{tabular}{|c|c|c|c|}
\hline مستوى دلالة t" & قيمة t المحسوبة & معامل التحديد & ترتيب دخول العناصر المستقلة في معادلة \\
\hline$\because \cdots$ & ג.YTT &.$\leqslant 70$ & البعد التنافسي \\
\hline$\because \cdots$ & $\varepsilon . \varepsilon \leqslant \lambda$ & .041 & البعد الإبداعي \\
\hline$\because \cdot 1 Y$ & T.017 & .007 & البعد الاسنقلالي \\
\hline
\end{tabular}

$$
\text { * ذات دلالة إحصائية على مستوى (م) }
$$

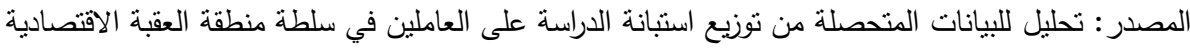
خرج من معادلة الانحدار المتعدد المتدرج متغيرات(بعد المخاطرة، البعد الاستباقي) 
الفرضية الفرعية الثانية: لا يوجد أثر ذو دلالة إحصائية عند مستوى دلالة (ه . . عـ) للاستثمار

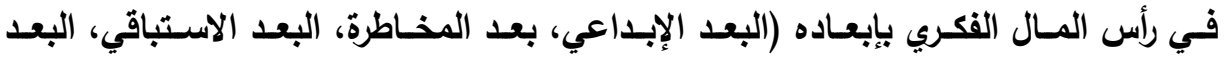
التنافسي، البعد الاستقلالي) في تحقيق التنفيذ الفعال للاستراتيجية كبعد من أبعاد النجاح

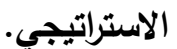

جدول رقم (1) - (1) - (1) - (1)

نتائج تحليل الانحدار المتعدد لاختبار اثر التوجه الريادي للمديرين بإبعاده المختلفة في التتفيذ الفعال للاسترانيجية.

\begin{tabular}{|c|c|c|c|c|c|}
\hline مستوى دلالة & قيمةt المحسوية & Beta & الخطأ & B & التوجه الريادي للمديرين \\
\hline$\because \cdots$ & *T.707 & .197 & $\because .04$ &. .194 & البعد الإبداعي \\
\hline. .191 & $* * 1.1 .9$ & $\because \cdot V T$ & $\because .07$ & 0.074 & بعد المخاطرة \\
\hline$\because \cdots$ & $* r .790$ & $\cdot r \leqslant V$ & $\because .09$ & $\cdot r \mid \Lambda$ & البعد الاستباقي \\
\hline$\because \cdots$ & $* 0.7 .5$ & $\because Y \wedge V$ & $\because .0 \mathrm{~V}$ & $\cdot M I r$ & البعد التتافسي \\
\hline$\because \cdots$ & *T.7IT &. $.19 \mathrm{~V}$ & $\because .09$ & $\cdot r \mid r$ & البعد الاستقلالي \\
\hline
\end{tabular}

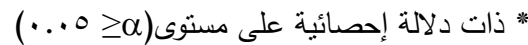

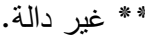

الصصدر : تحليل للبيانات الدتحصلة من توزيع استبانة الدراسة على العاملين في سلطة منطقة العقبة الاقتصادية يتضح من النتائج الإحصائية الواردة في الجدول رقم(1)، (1)، ومن متابعة قيم اختبار(t) أن المتغيرات الفرعية التالية والمتعلقة (البعد الإبداعي، البعد الاستباقي، البعد التتافسي، البعد

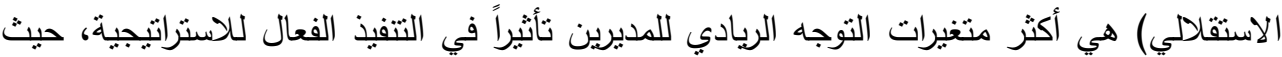

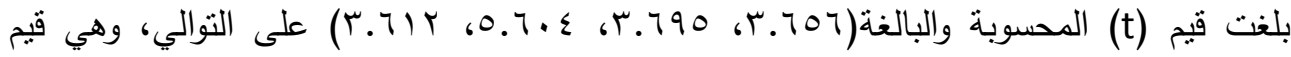

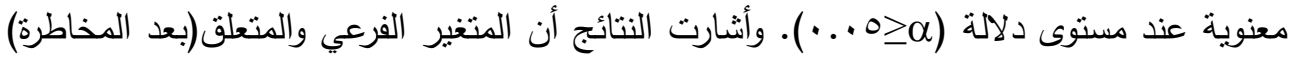
ليس لها أثز في التتفيذ الفعال للاستراتيجية، حيث كانت قيمة(t) المحسوبة غير دالة إحصائياً عند

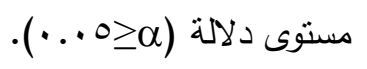

ومما سبق يقتضي ما يلي: رفض الفرضية الصفرية التي تتص على انه لا يوجد اثر هام

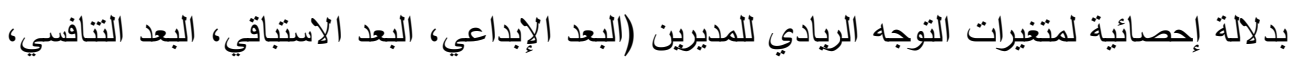

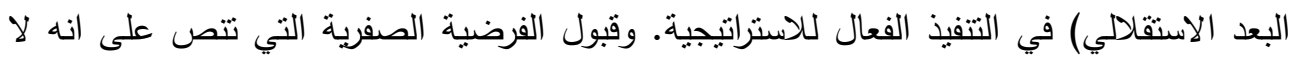
يوجد اثز هام بدلالة إحصائية لمتغير (بعد المخاطرة) في التتفيذ الفعال للاستراتيجية. وعند إجراء تحليل الانحدار المتعدد التنريجي Stepwise Multiple Regression لتحديد أهمية كل متغير مستقل على حدة في المساهمة في النموذج الرياضي، الذي يمثل أثز التوجه 
الريادي للمديرين (البعد الإبداعي، بعد المخاطرة، البعد الاستباقي، البعد التتافسي، البعد الاستقلالي)

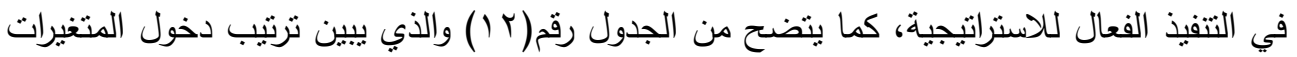

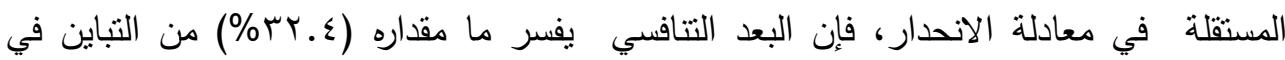

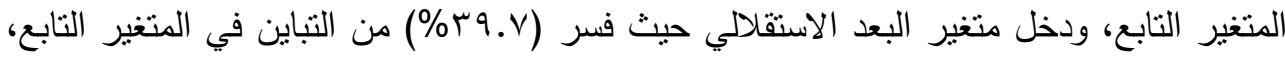

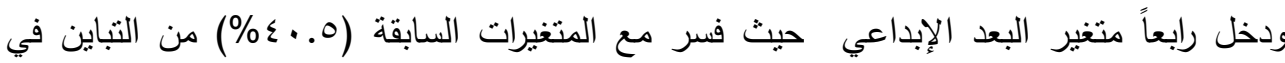

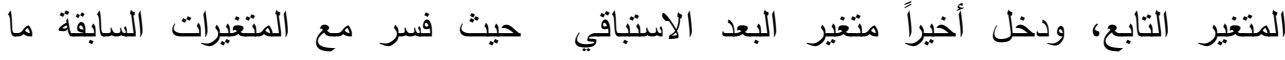
مقداره(1.1§\%) من التباين في التنفيذ الفعال للاستراتيجية كمتغير تابع. وخرج من معادلة الانحدار المتعدد المتدرج متغير (بعد المخاطرة) على اعتبار انها متغيرات ضعيفة وغير مهمة إحصائياً. ومرد هذه النتيجة أن تحقيق القدرة على المنافسة للمنظمات يتمثل في قدرة هذه المنظمات

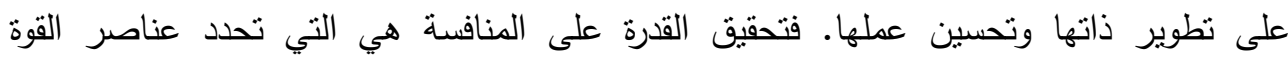
وعناصر الضعف والتي تساعد المنظمة في تحديد عناصر النجاح الحرجة وتستتر هذه العناصر

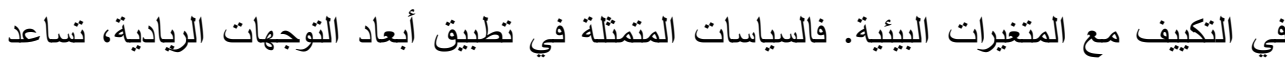

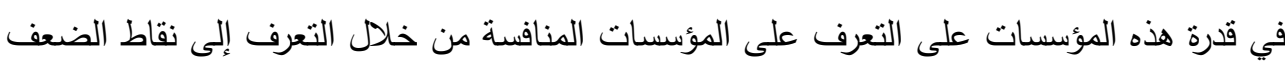

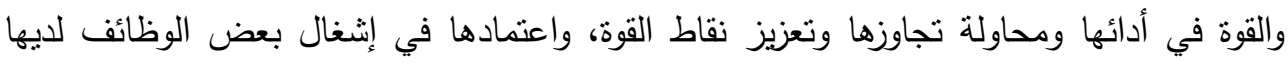
على استقطاب وجذب الأفراد من ذوبي الخبرة والكفاءة، وتشجيع العاملين وتعزيزهم على تطوير رقابته الذاتية عند أداء المهام المطلوبة منهم.

جدول (r)

نتائج تحليل الإنحدار المتعدد التنريجي " Stepwise Multiple Regression" للنتبؤ بالتنفيذ الفعال للاستراتيجية من خلال أبعاد التوجه الريادي للمديرين كمتغيرات مستقلة

\begin{tabular}{|c|c|c|c|}
\hline مستوى دلالة to & المحسوبة t & 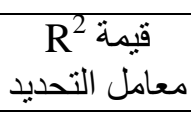 & ترتيب دخول العناصر المستقلة \\
\hline$\because \cdots$ & $* 0.071$ & $\cdot r r \leq$ & البعد التتافسي \\
\hline$\because \cdots$ & $* Y .007$ & $\cdot . r 9 V$ & البعد الاستقلالي \\
\hline$\because \cdots$ & *ะ. $1 \leqslant \varepsilon$ & $\because \leqslant .0$ & البعد الإبداعي \\
\hline$\because \cdots 1$ & $* r . \leqslant 09$ & $\because \Sigma 1 \wedge$ & البعد الاستباقي \\
\hline
\end{tabular}

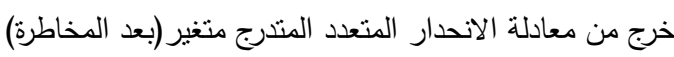

الكصدر : نحليل لليبانات المتحصلة من توزيع استبانة الدراسة على العاملين في سلطة منطقة العقبة الاقتصادية العادية

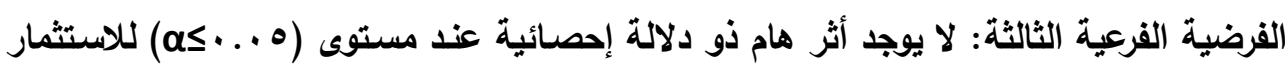

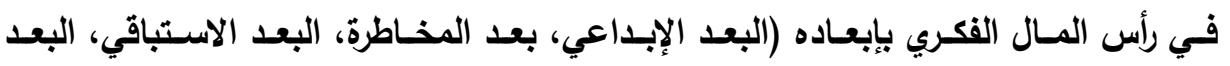




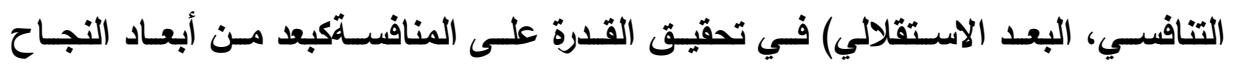
الاستراتيجي.

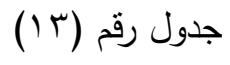

نتائج تحليل الانحدار المتعدد لاختبار اثر التوجه الريادي للمديرين بإبعاده المختلفة في القدرة على

\begin{tabular}{|c|c|c|c|c|c|}
\hline \multicolumn{6}{|c|}{ المنافسة. } \\
\hline دلانة دستوى & قالمسيوية & Beta & الخعياري & B & التوجه الريادي للمديرين \\
\hline$\because 71$ & $* * 1 . \wedge r \wedge$ & .1 .0 & $\because .00$ & 0.099 & البعد الإبداعي \\
\hline$\because 10$ & $* Y . \leqslant 0$. & $\because 1 \leqslant V$ & $\because .01$ & $\cdot .1 \leqslant r$ & بعد المخاطرة \\
\hline$\because I V Y$ & **). IV & $\because 911$ & $\because 71$ & 0.084 & البعد الاستباقي \\
\hline$\because \cdots$ & $* \leqslant .791$ &.$r 09$ &. .09 & $\because r \vee q$ & البعد التتافسي \\
\hline$\because \cdots$ & *0.rqr & . MI & $\because 7$. & (TMT & البعد الاستقلالي \\
\hline
\end{tabular}

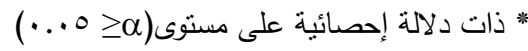

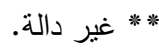

المصدر : تحليل للبيانات المنحصلة من توزيع استبانة الدراسة على العاملين في سلطة منطقة العقبة الاقتصادية

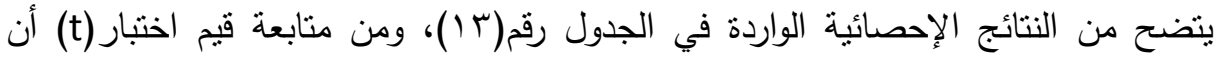

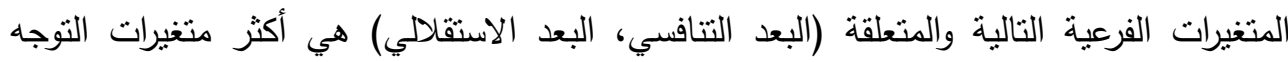

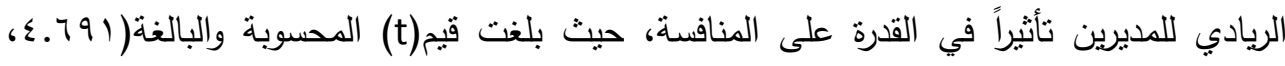

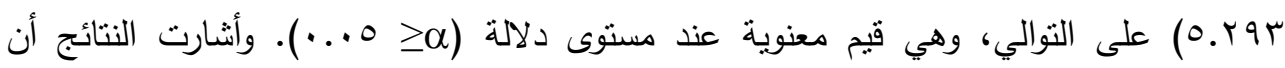

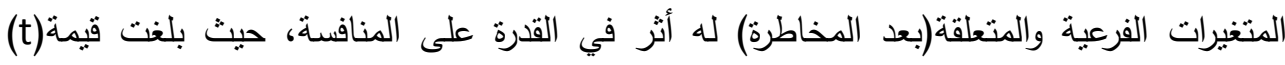

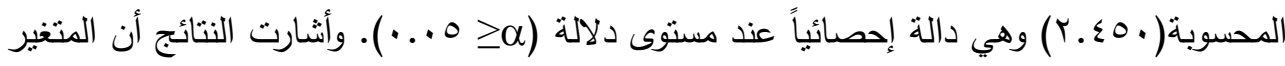

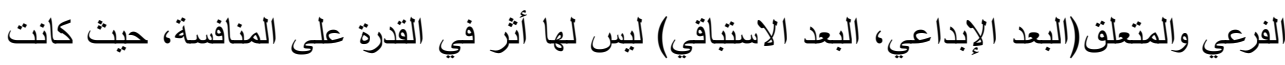

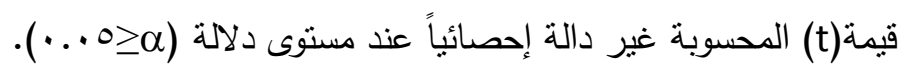
ومما سبق يقتضي ما يلي: رفض الفرضية الصفرية التي تتص على انه لا يوجد اثر هام

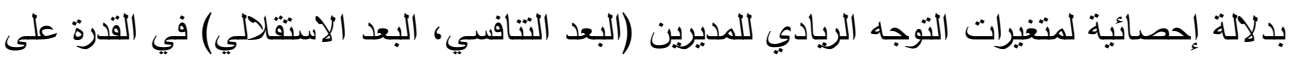

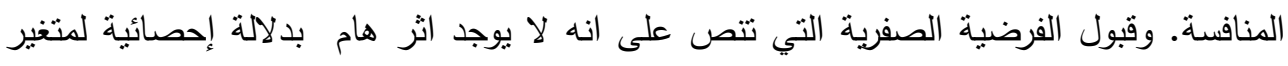
(البعد الإبداعي، البعد الاستباقي) في القدرة على المنافسة. وعند إجراء تحليل الانحدار المتعدد التنريجي Stepwise Multiple Regression لتحديد التيدي أهمية كل متغير مسنقل على حدة في المساهمة في النموذج الرياضي، الذي يمثل أثز التوجه 
الريادي للمديرين (البعد الإبداعي، بعد المخاطرة، البعد الاستباقي، البعد التتافسي، البعد الاستقلالي)

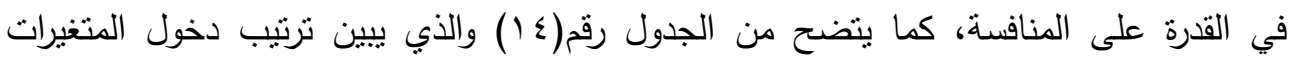

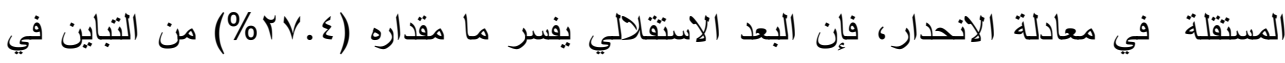

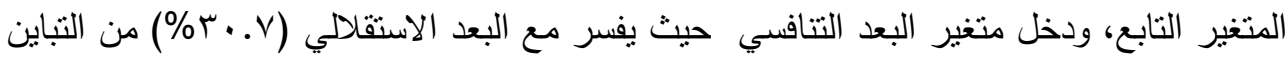

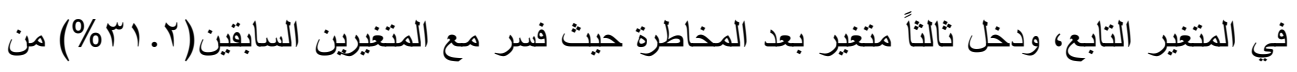

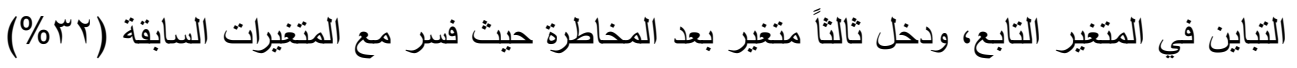
من التباين في القدرة على المنافسة كمتغير تابع. وخرج من معادلة الانحدار المتعدد المتدرج متغير (البعد الإبداعي، البعد الاستباقي) على اعتبار أنها متغيرات ضعيفة وغير منير مهمة إحصائياً. وتفسر هذه النتيجة أن سلطة منطقة العقبة الاقتصادية من خلال اختيار العئبة الموارد البشرية المؤهلة

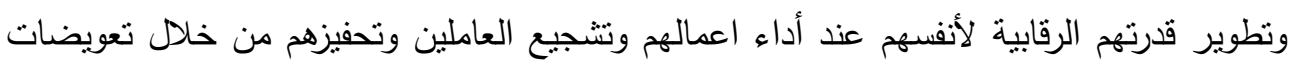

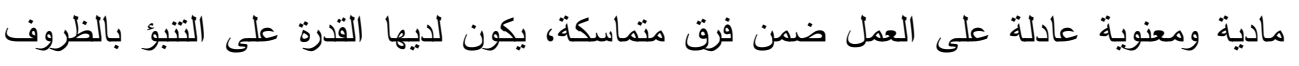

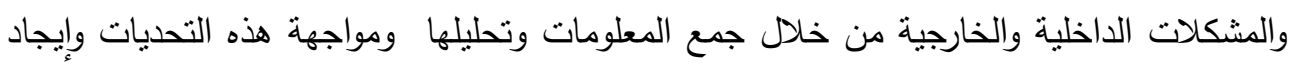
السبل اللازمة لإحتوئها والسبطرة عليها قدر الإمكان.

جدول (ع الإندان)

نتائج تحليل الإنحدار المتعدد التدريجي " Stepwise Multiple Regression" للتتبؤ بالقدرة على المنافسة من خلال أبعاد التوجه الريادي للمديرين كمتغيرات مستقلة

\begin{tabular}{|c|c|c|c|}
\hline مستوى دلالة t* & قيمة t المحسوبة & معامل التحديد & ترتيب دخول العناصر المستقلة في معادلة \\
\hline$\because \cdots$ & $0 . \sum \lambda 1$ & $\cdot T V \varepsilon$ & البعد الاستقلالي \\
\hline$\because \cdots$ & $\varepsilon .0 \leqslant$. & $\cdot r \cdot \nu$ & البعد التتافسي \\
\hline$\because \cdots \varepsilon$ & r.9T. & 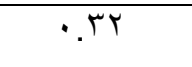 & بعد المخاطرة \\
\hline
\end{tabular}

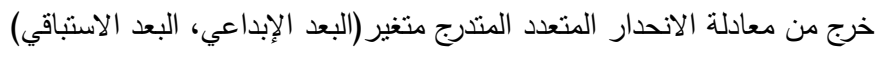

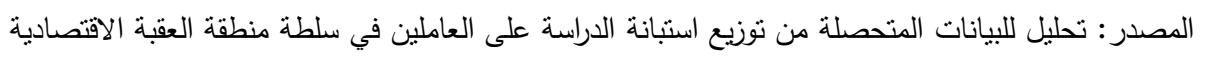

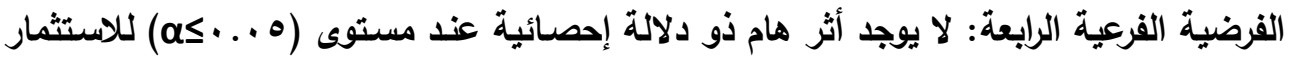

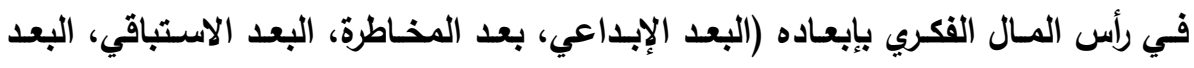

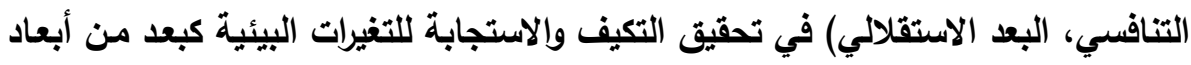
النجاح الاستراتيجي. 


$$
\text { جدول رقم (10) - جارئ }
$$

نتائج تحليل الانحدار المتعدد لاختبار اثر التوجه الريادي للمديرين بإبعاده المختلفة في التكيف والاستجابة للتغيرات البيئية.

\begin{tabular}{|c|c|c|c|c|c|}
\hline دلائة دستوى & قيمةt المحسوية & Beta & المعياري & B & التوجه الريادي للمديرين \\
\hline$\because \cdot r$ & *r. &. .171 & $\because 70$ &. $.1 \%$ & البعد الإبداعي \\
\hline$\cdot . T Y Y$ & ${ }^{* *} \cdot . \leqslant 9 \Gamma$ & $\because \cdot Y \wedge$ & $\because \cdot 7$ & $\because \cdot 9 \mathrm{~V}$ & بعد المخاطرة \\
\hline$\because \cdots$ & *T.7Tו & $\cdot . r 01$ & $\because 4 \pi$ & - rYq & البعد الاستباقي \\
\hline$\because \cdots$ & *ฯ.人०Y & אודית & $\because \cdot 71$ & $\cdot . \leqslant 11$ & البعد التتافسي \\
\hline$\because \cdots$ & *ะ.VTY & $\cdot r 7 \Lambda$ & . & e rYt & البعد الاستقلالي \\
\hline
\end{tabular}

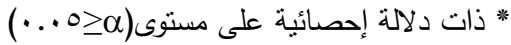

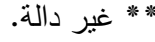

الكصدر : تحليل لليبانات المتحصلة من توزيع استبانة الدراسة على العاملين في سلطة منطقة العقبة الاقتصادية

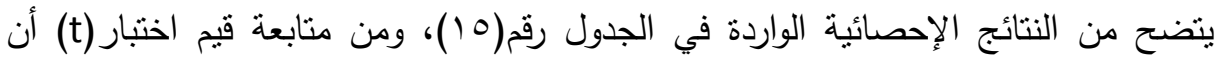

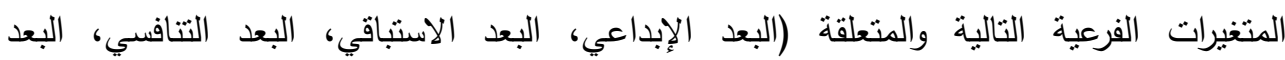

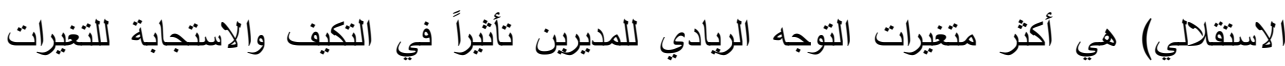

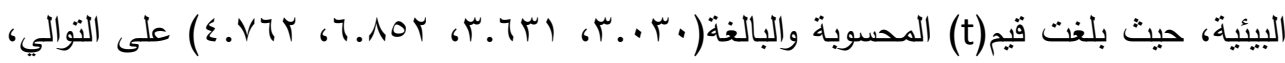

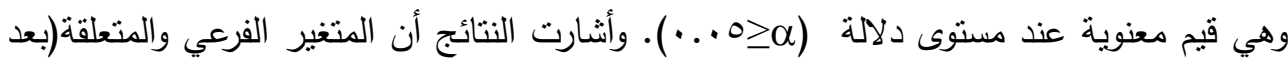

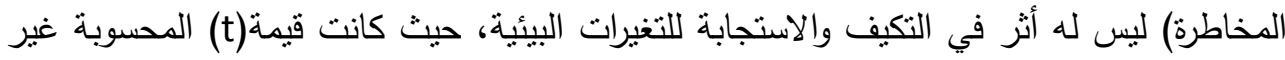

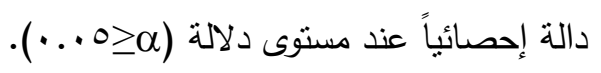

ومما سبق يقتضي ما يلي: رفض الفرضية الصفرية التي تتص على انه لا يوجد اثز هام

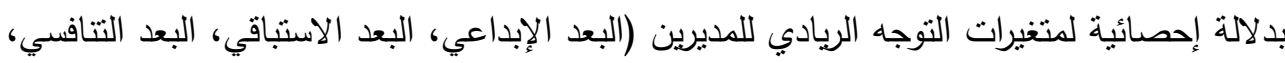

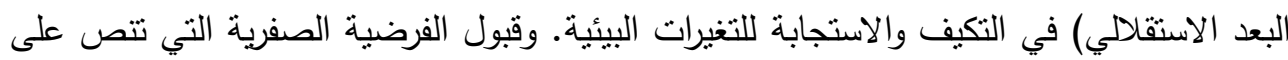
انه لا يوجد انز هام بدلالة إحصائية لمتغير (بعد المخاطرة) في التكيف والاستجابة للتغيرات البيئية. 
جدول (1) (1) (1) (2)

نتائج تحليل الإنحدار المتعدد التنريجي " Stepwise Multiple Regression" للتنبؤ بالتكيف والاستجابة للتغيرات البيئية من خلال أبعاد التوجه الريادي للمديرين كمتغيرات مستقلة

\begin{tabular}{|c|c|c|c|}
\hline مستوى دلالة to & قيمة t المحسوبة & معامل التحديد & ترتيب دخول العناصر المستقلة في \\
\hline$\because \cdots$ & $* V .111$ & $\cdot r q V$ & البعد التتافسي \\
\hline$\because \cdots$ & $* 0.90 \mathrm{~V}$ & • & البعد الاستقلالي \\
\hline$\because \cdots$ & $* \varepsilon .9 \vee r$ & $\cdot r \leqslant \varepsilon$ & البعد الاستباقي \\
\hline$\because \cdot 1$. & *T. & $\cdot$ rov & البعد الإبداعي \\
\hline
\end{tabular}

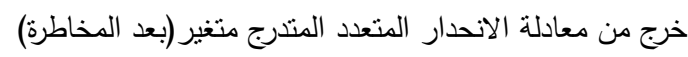

المصدر : تحليل للبيانات المتحصلة من توزيع استبانة الدراسة على العاملين في سلطة منطقة العقبة الاقتصادية وعند إجراء تحليل الانحدار المتعدد التنريجي Stepwise Multiple Regression لتحديد أهمية كل متغير مسنقل على حدة في المساهمة في النموذج الرياضي، الذي يمنل أثز التوجه النهاه الريادي للمديرين (البعد الإبداعي، بعد المخاطرة، البعد الاستباقي، البعد التتافسي، البعد الاسنقلالي) في التكيف والاستجابة للتغيرات البيئية، كما يتضح من الجدول رقم(7 ( ) والذي يبين ترتيب دخول

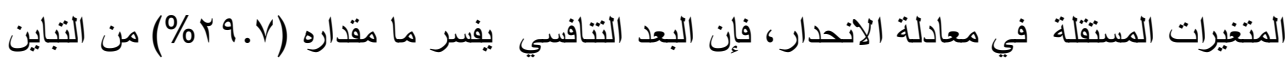

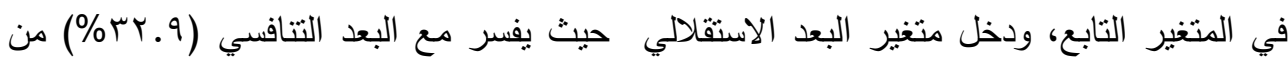

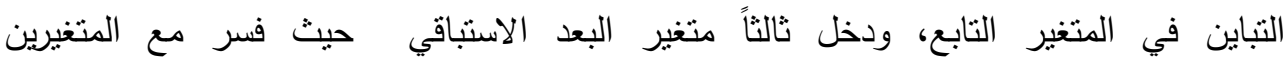

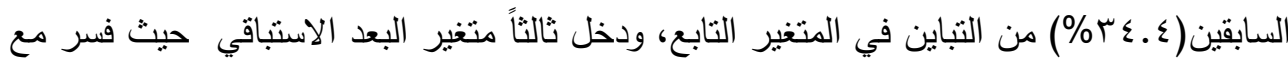

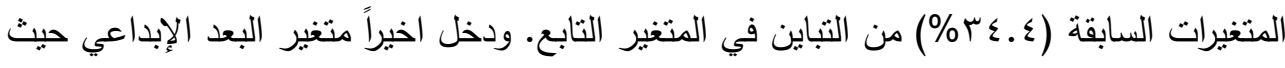

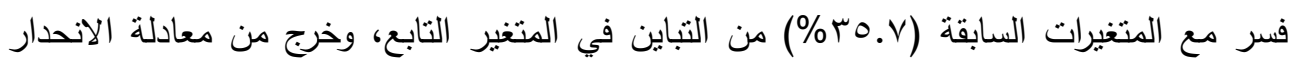

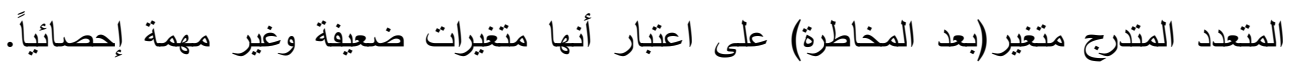

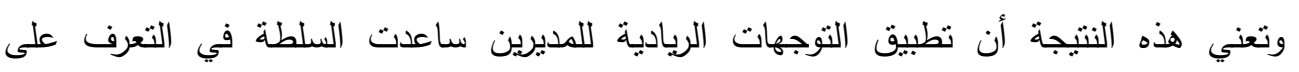

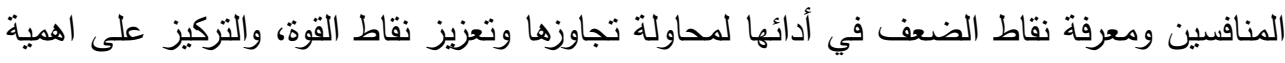

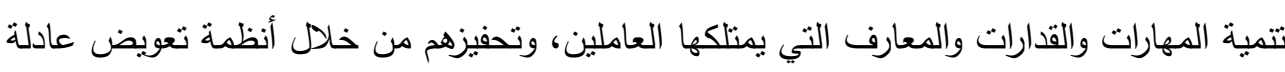
وتتبع إحتباجتهم وتدفعهم الى التفكير الملهم والابداع في أداء العمل، وتطوير مراقبتهم لأداء أعمالهم بأنفسهم دون الحاجة الى تعزيز أنظمة رقابة صلى صارمة عليهم. 


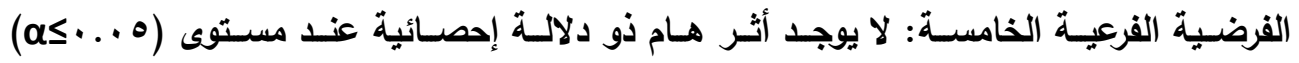

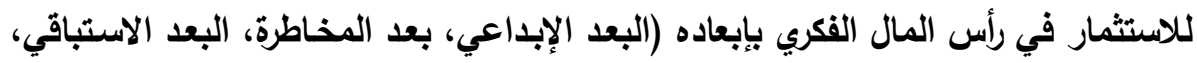

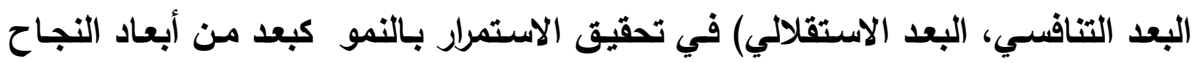

$$
\text { جدول رقم (lv) (ل) }
$$

نتائج تحليل الانحدار المتعدد لاختبار اثر التوجه الريادي للمديرين بإبعاده المختلفة في الاستمرار

\begin{tabular}{|c|c|c|c|c|c|}
\hline \multicolumn{6}{|c|}{ بالنمو • } \\
\hline دلاكة t & قيمةt المحسوية & Beta & المعياري & B & التوجه الريادي للمديرين \\
\hline$\because \cdots$ & *T.NOY & $\cdot . r \cdot 9$ & $\because .07$ & $\cdot r) \leqslant$ & البعد الإبداعى \\
\hline$\because \cdots 0$ & $* Y . \wedge \cdot \Lambda$ &. .101 & $\because .09$ &. $.17 \mathrm{~V}$ & بعد المخاطرة \\
\hline$\because \cdots$ & ${ }^{*} T . V \varepsilon r$ & $\because Y O \varepsilon$ & $\because \cdot T r$ & •.YTr & البعد الاستباقي \\
\hline$\because \cdots$ & $* 7.00$. & $\cdot r \leqslant 1$ & $\because \cdot 7$ & $\cdot . r 97$ & البعد التنافسى \\
\hline$\because \cdots$ & *々. TV々 & • & $\because .71$ &. .107 & البعد الاستقلالي \\
\hline
\end{tabular}

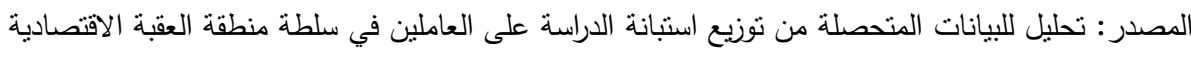

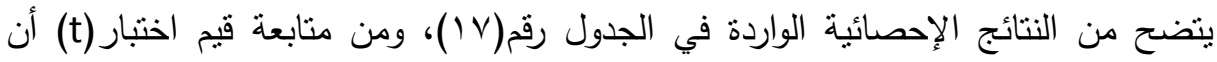

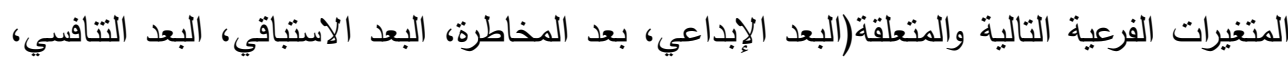

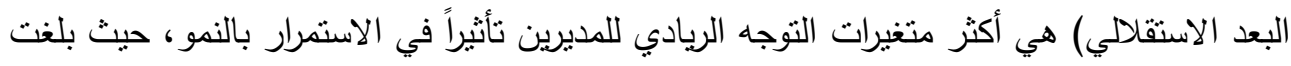

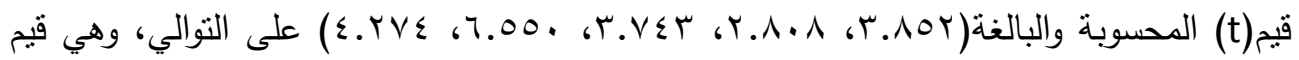

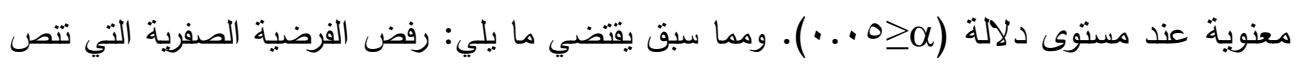

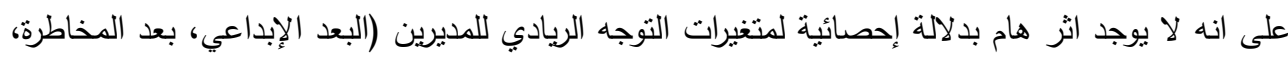

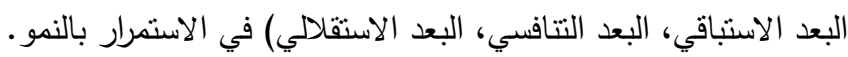

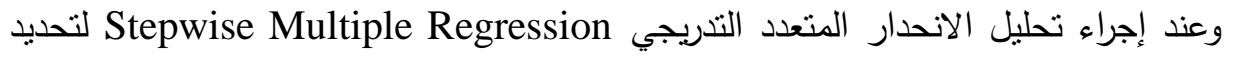
أهمية كل متغير مستقل على حدة في المساهمة في النموذج الرياضي، الذي يمثل أثز التوجه الريادي للمديرين (البعد الإبداعي، بعد المخاطرة، البعد الاستباقي، البعد التتافسي، البعد الاستقلالي) في الاستمرار بالنمو، كما يتضح من الجدول رقم(1) والذي يبين ترتيب دخول المتغيرات المستقلة

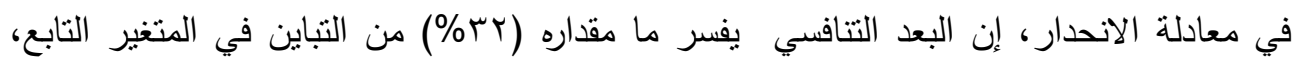

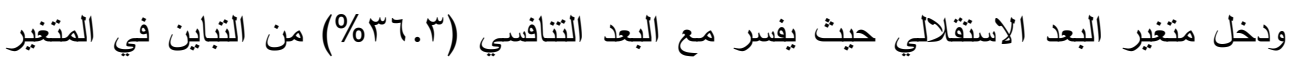
التابع، ودخل ثالثاً متغير البعد الإبداعي حيث فسر مع المتغيرين السابقين(r.یr\%) من التباين 
في المتغير التابع، ودخل رابعاً متغير البعد الاستباقي حيث فسر مع المتغيرات السابقة (1.9\%\%)

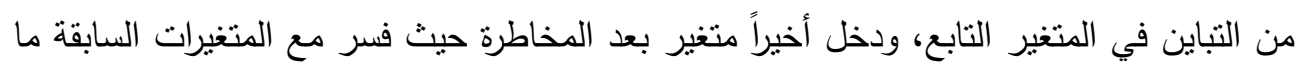
مقداره( (. ؛ \%) من التباين في الاستمرار بالنمو كمتغير تابع. وتفسر هذه النتيجة أن السلطة لديها

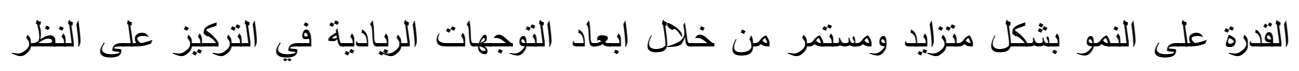

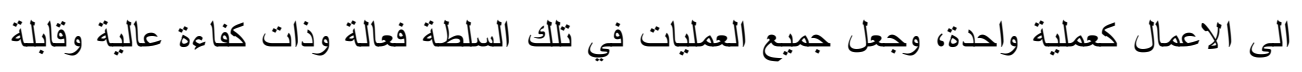
للتكيف، وكذلك الحرص على تطبيق السياسات والبرامج الكفيلة في تحقيق النجاح الاستراتيجي من خلال الاهتمام بالتغيرات المحيطة بها، يحث يربط ذلك بالتركيز على تأهيل العاملين وزيادة قدراتهم الابتكارية وتحفيزهم بانظمة حوافز عادلة.

$$
\text { جدول (1) (1) }
$$

نتائج تحليل الإنحدار المتعدد التدريجي "Stepwise Multiple Regression" للتنبؤ بالاستمرار

\begin{tabular}{|c|c|c|c|}
\hline مستوى دلالة t & قيمة t الدحسوبة & معامل التحديد & ترتيب دخول العناصر المستقلة في \\
\hline$\because \cdots$ & 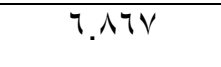 & $\cdot r r \cdot$ & البعد التنافسي \\
\hline$\because \cdots$ & $\varepsilon .790$ & ט & البعد الاستقلالي \\
\hline$\because \cdots$ & $r .9 Y r$ & . זה & البعد الإبداعي \\
\hline$\because \cdots$ & $r .79 r$ & $\cdot .991$ & البعد الاستباقي \\
\hline$\because \cdots r$ & r.9人r & $\cdot \varepsilon \cdot 1$ & بعد المخاطرة \\
\hline
\end{tabular}

الصصدر : نحليل للبيانات المتحصلة من نوزيع استبانة الدراسة على العاملين في سلطة منطقة العقبة الاقتصادية

$$
\text { بناءاً على النتائج التي توصلت إليها الدراسة فإنها توصي بما يلي: }
$$

ا ـ نظراً لوجود اثر للتوجه الريادي في تحقيق النجاح الاستراتيجي، تأكد الدراسة على ضرورة تبني

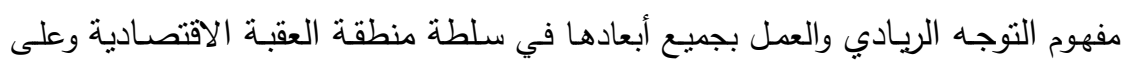

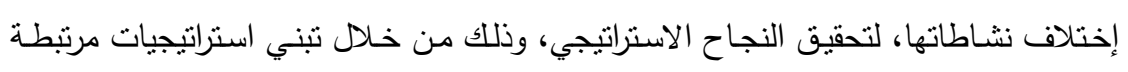
بالتوجهات الريادية نسهم في توسيع فهم الادارات العليا في سلطة منطقة الجنة العقبة الاقتصنادية

$$
\text { لتحقيق النجاح الإستراتيجي. }
$$

r. الإهتمام بنتائج تأثثر التوجهات الريادية لـات تحققه من ايجابيات على مستوى السلطة والعاملين

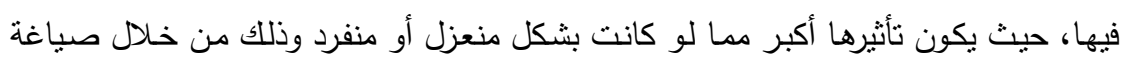
استراتيجيات تعكس وضوح رؤيا ورسالة وأهداف سلطة منطقة العقبة بنّة الاقتصادية. 
r. تتقيف العاملين بأهمية تبني سلوكاً ريادياً يُمكّن سلطة منطقة العقبة الاقتصادية من التفوق على

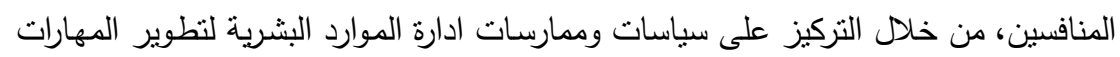
المتعلقة بإدارة الأفراد والزبائن والموردين في سلطة منطقة العقبة الاقتصادية.

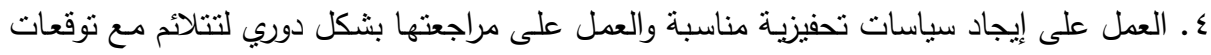

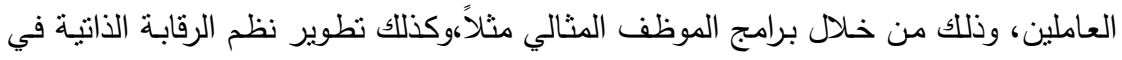

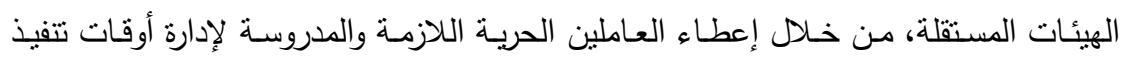

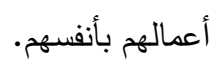
ه. تعزيز الثراكة بين سلطة منطقة العقبة الاقتصادية والجامعات بما بساعد في تحويل الأفكار

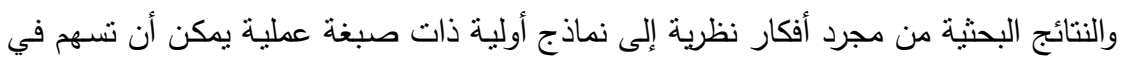

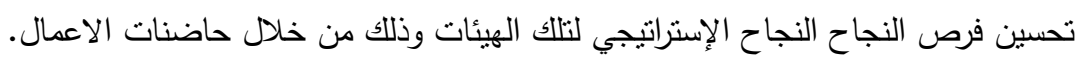

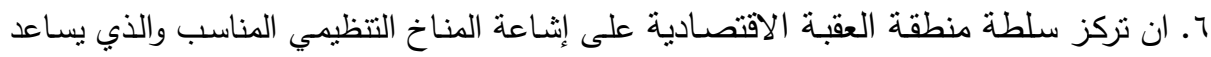

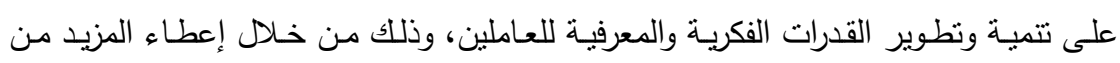

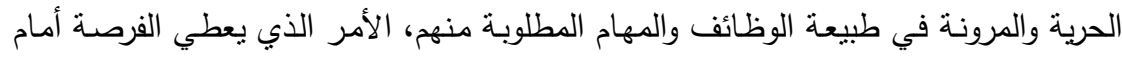
العاملين للإبداع والابتكار ضمن هذه الوظائف ويساهم في تحقيق النجاح الاستراتيجي.

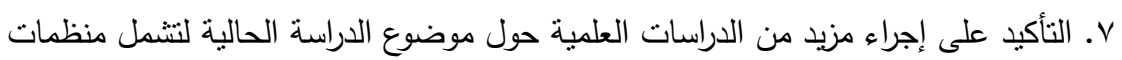
وعينات أخرى لتعميم نتائجها وتقديم توصيات بثأنها.

\section{المراجع

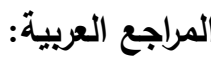

بني حمدان ، خالد محمد ، ادريس ، وائل محمد صبحي ، عبد الرحمن ، ربى رشيد (2013) ،

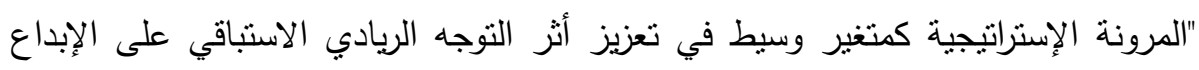

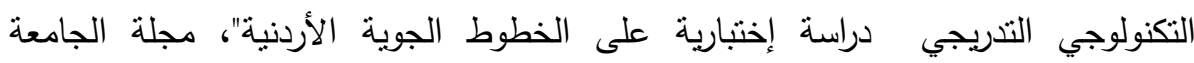

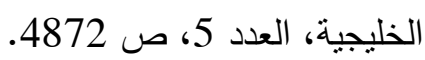

التميمي، إياد فاضل محمد والخشالي، شاكر جارالة، (10 ب ب)،" أثر مقومات التحالف الإستراتيجي في تحقيق النجاح الإستراتيجي"، دراسة نطبيقية في البنوك التجارية العاملة في الأردن"، المجلة الأردنية في إدارة

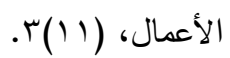

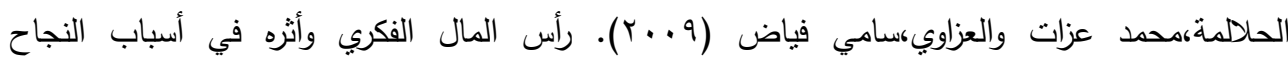

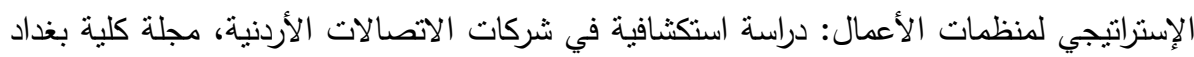

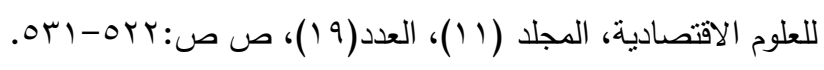

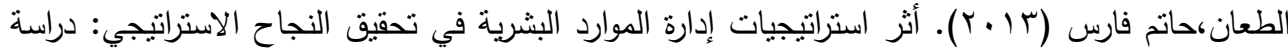

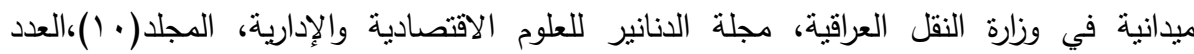

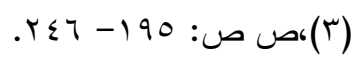




$$
\begin{aligned}
& \text { العجالين، توفيق عبد الغني (2015)، " أنزر الخصائص الريادية في الفاعلية التنظيمية : الدور } \\
& \text { الوسيط للتوجهات الاستراتيجية _ دراسة ميدانية في الثركات المتوسطة والصغيرة في مدينة } \\
& \text { عبد الله الثاني ابن الحسين الصناعية الأردن" ، أطروحة دكتوراه غير منشورة ، جامعة } \\
& \text { العلوم الإسلامية العالمية، الأردن. } \\
& \text { العجمي، عبد المحسن سالم (2013)،" دور التوجه الريادي في تحقيق التفوق التتافسي للبنوك } \\
& \text { التجارية الكويتية"، ( رسالة ماجنتير غير منشورة )، الجامعة الأردنية؛ عمان ، الأردن . }
\end{aligned}
$$

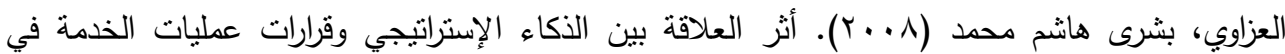

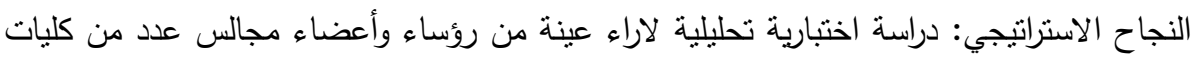

$$
\begin{aligned}
& \text { جامعة بغداد، كلية الإدارة والاقتصاد، جامعة بغداد، العراق. } \\
& \text { الغانم، سلمان عبداله سلمان (2011)،" أثز التوجه الريادي والمرونة الإستراتيجية على الإبداع }
\end{aligned}
$$

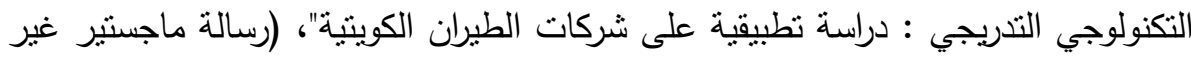

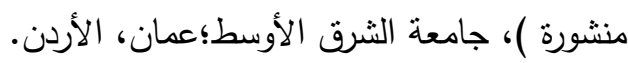

$$
\begin{aligned}
& \text { القرنة ، لميس يوسف (2014)، " أثز أبعاد المنظمة الريادية في تحقيق التنافسية المستدامة دراسة }
\end{aligned}
$$

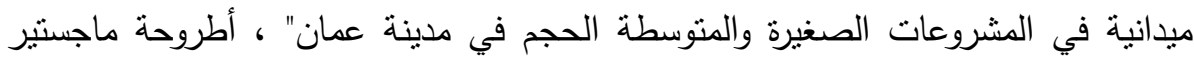

$$
\begin{aligned}
& \text { غير منشورة ، جامعة الثرق الأوسط ، عمان، الأردن. }
\end{aligned}
$$

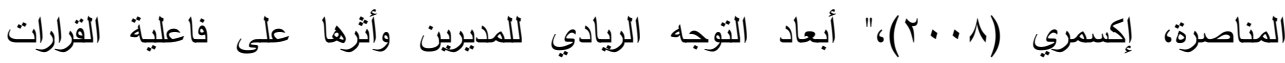

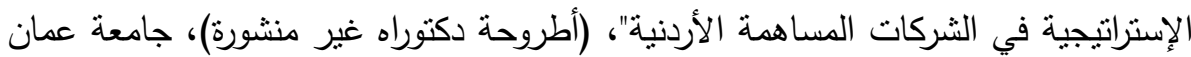

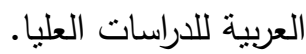

$$
\begin{aligned}
& \text { المراجع الأجنبية }
\end{aligned}
$$

Al-Damen, R. A., (2015), "The Impact of Entrepreneurs' Characteristics on Small Business Success at Medical Instruments Supplies Organizations in Jordan", International Journal of Business and Social Science, Vol. 6, No. 8.

Amoli, J, Aghashahi,F. (2016). An Investigation on Strategic Management Success Factors in an Educational Complex, Social and Behavioral Sciences. (230), $447-454$

Covin, J.G; Green, kimberly M\& Slevin, Dennis (2006), "Strategic process effects on the entrepreneurial orientation sales growth rate relationship", Entrepreneurship theory \& practice, Vol.30, NO.1:5781.

Dahleez, K. A., and Migdad, M. I., (2013). " Entrepreneurial Characteristics of Undergraduate Students in Deteriorated Economies (the case of Gaza Strip)", Dirasat, Administrative Sciences, Vol. 40, No. 2. 
David, F. R., (2009). Strategic Management: Concepts and Cases, New Jersey, Prentice Hall Inc.

Dess , Gregory G., Lumpkin ,G.T.\& Eisner ,Alan B. (2007), "Strategic Management: Creating competitive Advantage", McGraw-Hill, Barded. New York.

Fairoz, Fauzul mafasiya; Hirobumi , Takenochi \& Tanaka, Yukiko (2010), " Entrepreneurial orientation and business performance of small and medium scale enterprise of hambanota district Sri lanka ",Asian social science, vol 50, no.2; 305324.

Hafeez, s; Chauhry , R,M; Siddiqui, Z.U \& Rehman k.u (2011) , " The effect of market and entrepreneurial orientation on firm performance", Information management and business review, vol.3,No.6: 389395 .

Herath, H. M. A., \& Mahmood, R. (2013). Strategic orientation based research model of SME performance for developing countries. Review of Integrative Business and Economics Research, 2(1), 430.

Huang,K.P.,Wang,K.Y.,Chen,K.H., and Yien, J.M. ( $+1 \uparrow)$." Revealing the effects of Entrepreneurial orientation on firm performance: A conceptual approach", Journal of Applied Science,11(16):3049-3052.

Luke, Belinda \& Verreynne, Martie-Louise, (2006), "Exploring strategic entrepreneurship in the public sector", Qualitative Research in Accounting \& Management, Vol. 3 No. 1: 4-26

Meibodi, L. A. and Monavvarian, A. (2010). Factors of strategic success in business organizations , Business Strategy Series, 11(2): 124-133.

Mousa, F.T, Wales, W.(2012) " Founder effectiveness in leveraging entrepreneurial orientation", Management decision, Vol 50, No.2: 305324.

Peng Shan, Michael Song, Xiaofeng Ju (2016) " Entrepreneurial orientation and performance: Is innovation speed a missing link?" ,Journal of Business Research, Volume 69, Issue 2, Pages 683690.

Renko, maija\& Malin (2010) " The effect of market orientation entrepreneurial orientation, and Technological capability on innovativeness: A study of young biotechnology venture united state and Scandinavia", journal of small business management ,Vol. 47, No.3: 331369.

Sara.J,Aghashahib.F,(2016),"An Investigation on Strategic Management Success Factors in an Educational Complex", Social and Behavioral Sciences, (9)3, 447 - 454. 